Florida International University FIU Digital Commons

\title{
The effect of instruction on the study behaviors and academic achievement of community college students
}

\author{
Zoraya Maria Cuesta \\ Florida International University
}

DOI: $10.25148 /$ etd.FI14061556

Follow this and additional works at: https://digitalcommons.fiu.edu/etd

Part of the Higher Education Commons

\section{Recommended Citation}

Cuesta, Zoraya Maria, "The effect of instruction on the study behaviors and academic achievement of community college students" (2007). FIU Electronic Theses and Dissertations. 2680.

https://digitalcommons.fiu.edu/etd/2680 
FLORIDA INTERNATIONAL UNIVERSITY

Miami, Florida

THE EFFECT OF INSTRUCTION ON THE STUDY BEHAVIORS

AND ACADEMIC ACHIEVEMENT

OF COMMUNITY COLLEGE STUDENTS

A dissertation submitted in partial fulfillment of the

requirements for the degree of

DOCTOR OF EDUCATION

in

HIGHER EDUCATION

by

Zoraya Maria Cuesta

2007 
To: Interim Dean Judith Blucker

College of Education

This dissertation, written by Zoraya Maria Cuesta, and entitled The Effect of Instruction on the Study Behaviors and Academic Achievement of Community College Students, having been approved in respect to style and intellectual content, is referred to you for judgment.

We have read this dissertation and recommend that it be approved.

Dawn Addy

Cengiz Alacaci

Janice R. Sandiford

Leonard B. Bliss, Major Professor

Date of Defense: March 28, 2007

The dissertation of Zoraya Maria Cuesta is approved.

Interim Dean Jưdith Blucker College of Education

Dean George Walker University Graduate School

Florida International University, 2007 


\section{DEDICATION}

I dedicate this dissertation to my parents for their constant support and unconditional love. 


\section{ACKNOWLEDGMENTS}

The completion of this dissertation has been the dream of my life, and in order to accomplish such a significant goal everyone needs the assistance and expertise of many creative, knowledgeable, and unselfish individuals. First of all I must thank the Lord for giving me this immense opportunity to live in this land of freedom where dreams can be achieved with effort and tenacity. Second, I would like to thank my committee members Dr. Cencie Alacaci, Dr. Dawn Addie, and Dr. Janice R. Sandiford for all their efforts in assisting me to complete this dissertation; my family and friends for believing in me and supporting me throughout this long journey; my colleague, mentor, and friend $\mathrm{Mr}$.

Thomas M. Halloran for all his support, motivation, and encouragement to persevere in the accomplishment of this milestone in my life. I will always be grateful for all his assistance and guidance; and especially I would like to take this opportunity to express my sincere gratitude and respect to my Chairperson Dr. Leonard Bliss and Dr. Linda Bliss, for their guidance, support, infinite knowledge, and extraordinary dedication in helping me achieve my doctoral degree. I will always be indebted to them, and I appreciate everything that they have done for me. Without their assistance and support I would have never finished my dissertation. Thank you for all your efforts. 


\title{
ABSTRACT OF THE DISSERTATION
}

THE EFFECT OF INSTRUCTION ON THE STUDY BEHAVIORS AND ACADEMIC ACHIEVEMENT OF COMMUNITY COLLEGE STUDENTS

\author{
by \\ Zoraya Maria Cuesta \\ Florida International University, 2007 \\ Miami, Florida \\ Professor Leonard B. Bliss, Major Professor
}

The purpose of this study was twofold. It was designed to determine (a) the efficacy of an intervention designed to increase the frequencies of appropriate study behaviors on the part of community college students who were preparing for academic mathematics activities and (b) whether any increase in appropriate study behavior frequency was accompanied by increased academic achievement in college preparatory mathematics classes.

A total of 126 Miami Dade College students participated in this study. Two developmental (remedial) mathematics classes were randomly assigned as the experimental group, and two others were assigned as the control group. All students also took a College Survival (SLS) class. The Study Behavior Inventory (SBI) and the Computerized Placement Test (CPT) were administered to the four classes. The SBI was used as a pre- and post-test. The SLS curriculum and classroom time were the same for both groups. However, students in the treatment groups received instruction designed to increase the frequency of effective study behaviors associated with the three factors 
identified in the SBI, while the students in the control group participated in activities that did not emphasize study behaviors.

A series of analysis of covariance procedures were used to analyze four hypotheses. The first three hypotheses proposed that students who were instructed in the use of appropriate study behaviors would score higher on the three factors of the Study Behavior Inventory than those who were not. The fourth hypothesis proposed that a greater proportion of mathematics students who were instructed in the use of appropriate study behaviors would receive a passing grade in their course than students who were in the control group. The four hypotheses were tested at the .05 level of significance.

This study revealed that students who received instruction in appropriate study behaviors scored higher in the use of appropriate study behaviors and in mathematics achievement than students who did not. Additional research is needed to investigate whether these effects would persist over time, or be found in subjects other than mathematics. 


\section{TABLE OF CONTENTS}

CHAPTER

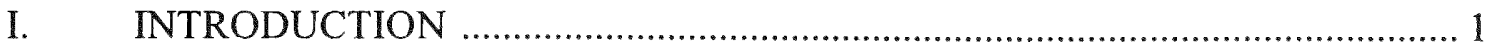

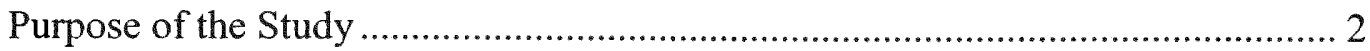

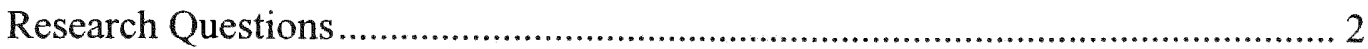

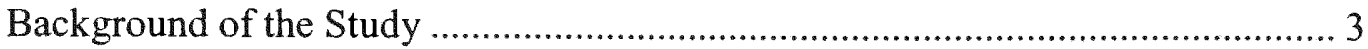

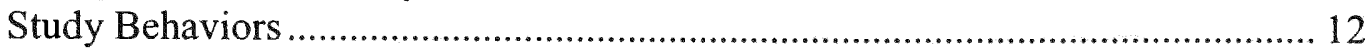

Significance of the Study ….............................................................................. 18

Delimitations of the Study …......................................................................... 18

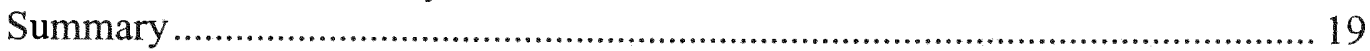

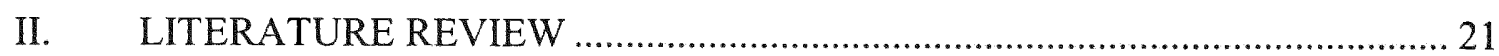

Student Retention: A Problem at Community Colleges ...................................... 21

Academic Success: Bandura's Social Cognitive Theory .................................... 24

Study Behavior and Academic Achievement …….............................................. 31

Improved Study Behaviors and Increased Academic Achievement.................... 35

Student Retention: Helping Community College Students ................................. 38

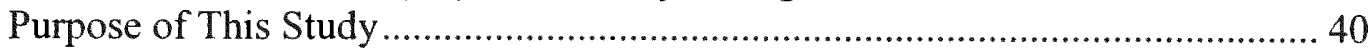

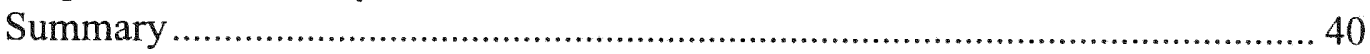

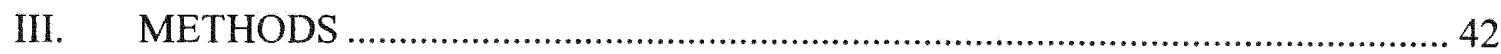

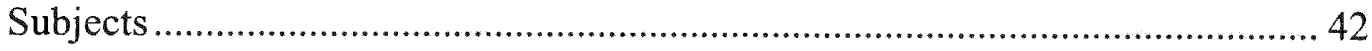

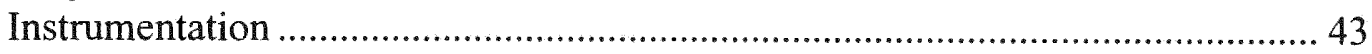

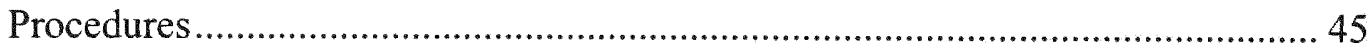

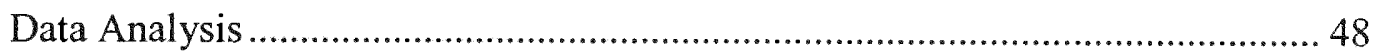

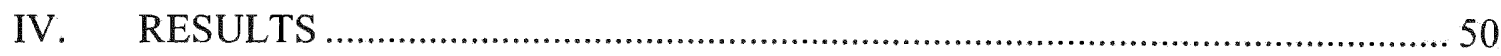

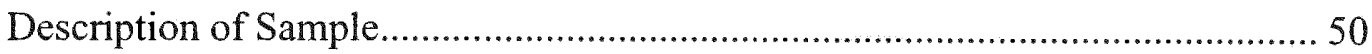

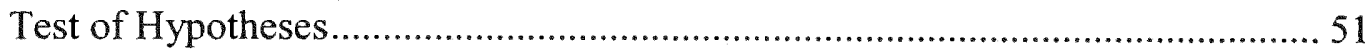

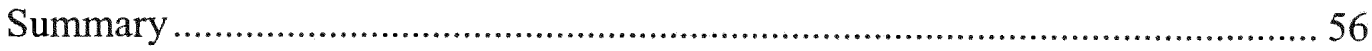

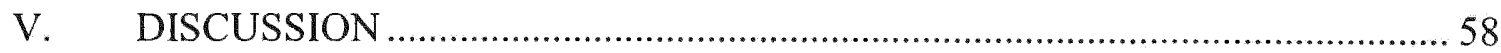

Discussion of the Findings .................................................................................. 59

Conclusions and Recommendations for Practice and Future Research............... 65

REFERENCES …

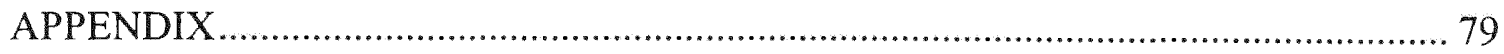

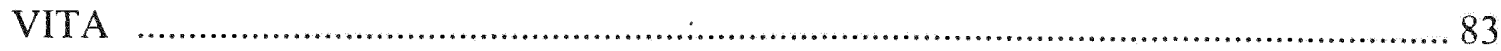




\section{CHAPTER I}

\section{INTRODUCTION}

One of the problems facing institutions of higher education in the United States is the fact that more and more students are entering these institutions who are less than adequately prepared to achieve in college and university level courses. These students are usually placed in developmental courses designed to provide them with the necessary skills, knowledge, and attitudes that will allow them to succeed in the institution's regular courses. As common as these developmental programs and courses are, however, there is little evidence of their efficacy (National Center for Education Statistics, 2002).

Developmental programs and classes tend to deal with reading, writing, and mathematics skills. Among these, in no other area is the tension between students' aspirations and the results of developmental education more starkly found than in the general area of mathematics. This is the area in which the greatest numbers and percentages of entering college students show serious deficiencies when they take their screening tests upon entrance. These deficiencies in mathematics skills also keep the largest numbers of students from completing their remediation programs prior to pursuing academic-level studies. The courses in which the greatest numbers of college students fail as they progress through their general education curriculum are also the required academic mathematics courses. This is a particular concern at community colleges where open enrollment policies often result in the admittance of high proportions of students who are underprepared to take college level mathematics courses.

Researchers have been exploring the question of why mathematics is such a barrier to success for college students. A number of studies have found that a likely 
explanation is a deficiency in study behaviors and skills that inhibits these students from achieving their academic goals (Faro-Schroeder, 1995; Morris, 2003). Therefore, there is good reason to expect that improvements in study behaviors among students who enter college with basic skill deficiencies, especially in mathematics, can result in higher rates of success in the required basic skills courses.

\section{Purpose of the Study}

The purpose of this research was twofold. First, it was designed to determine the efficacy of an intervention designed to increase the frequencies of appropriate study behaviors on the part of community college students who are preparing for academic mathematics activities. Next, it was designed to determine whether this increase in appropriate study behavior frequency is accompanied by increased academic achievement in developmental (college preparatory) mathematics courses as measured by course grades.

\section{Research Questions}

This study examined the effect of instruction in appropriate study behaviors among college preparatory mathematics students in order to determine if there is evidence to suggest that there is a cause and effect relationship between levels of appropriate study behaviors and the achievement of community college students in these mathematics courses. Specifically, the research questions were:

1. Does instruction in the use of appropriate study behaviors (while preparing for academic activities) increase the frequencies of these activities as measured by the Study Behavior Inventory in college students? 
2. Does instruction in appropriate study behaviors increase course grades for college students?

Among the studies that suggest this relationship between effective study behaviors and academic success, studies by Nokes and Ohlsson (2001) and by Tobias (1993) focused on the inculcation and repetition of behaviors that have been shown to assist in learning abstract subject matter, such as mathematics.

Another way of viewing the problem that was investigated is as an effort to determine how to ameliorate the low rate of success in remedial mathematics courses among community college students who are required to participate in these courses. Their current low rate of success in these courses results in a high rate of attrition among the unsuccessful students (Boylan et al., 1999).

\section{Background of the Study}

There has long been concern about the attrition and retention rates of higher education students in the United States. In recent years more time and attention has been devoted to identifying intervention strategies that will promote students' retention and success rates in higher education institutions.

According to Brawer (1995), an estimated $50 \%$ of the freshmen student population enrolled in colleges and universities drop out before completing their degrees. Also, Astin (1985), Pascarella and Terenzini (1998), and Tinto (1975) found in their research that, due to lower motivation and academic ability, 2-year college students have a much greater probability of dropping out than 4-year college students. The work of such scholars as Feldman (1993), House (2000), McGrath and Baunstein (1997), and 
Pascarella (1986) also strongly suggest a connection between academic achievement and attrition in higher education.

\section{Retention and Student Readiness}

The problems presented by high numbers of underprepared students enrolling in community colleges, with concomitant low levels of student retention that higher education is facing nowadays, is found throughout the United States. For instance, at Prince George's Community College, in Maryland, approximately $70 \%$ of new students needed remediation in at least one area, and the passing rate of students in remedial mathematics courses was only 50\% (Seon \& King, 1997).

This study was conducted at Miami Dade College where the same problem of large numbers of underprepared students has been noted. Every year more than $70 \%$ of new students need remediation in at least one area (MDC Institutional Research, 2003). The institution had, until recently, been known as Miami-Dade Community College and changed its name when it began offering a bachelor's degree in Secondary Mathematics, Secondary Science, and Exceptional Student Education. The primary roles of this large, multi-campus urban institution remain the educating of students for the Associate of Arts degree and providing certificate training for members of the community. During the academic year 2005-2006, Miami Dade College enrolled 79,845 Associate in Arts and Associate in Science students. Demographically, the student population at Miami Dade College is $22.0 \%$ African-American, $64.7 \%$ Hispanic, $10.3 \%$ Caucasian non-Hispanic, and $3.0 \%$ Other. Further, the student body at the College is $60.9 \%$ female and $39.1 \%$ male, with a mean age of 27.02 years old (MDC Institutional Research, 2006). Demonstrating a problem in retention, it was noted that at the North Campus of Miami 
Dade College during the 2001-2002 academic year, of 16,000 enrolled students, only 954 received Associate degrees by the end of the year (MDC Institutional Research, 2003).

Since 1991, the percentage of Florida public high school graduates pursuing postsecondary education in the state of Florida has risen by ten percentage points. But $61 \%$ of those students who graduated in 1991 had not earned any higher-level credential after 10 years (National Center for Education Statistics, 2002). This issue became even more complex in the next 2 years, since many students who completed 4 years of high school, but could not obtain a diploma due to repeated failure of the Florida Comprehensive Assessment Test, a high stakes achievement test used in Florida public schools, then enrolled in remedial courses at Florida community colleges (Florida Department of Education, 2003).

\section{Failing Mathematics Classes}

The proportion of students who are enrolling in programs at community colleges who are not prepared to begin college courses is increasing steadily. This is demonstrated by a 2001 Florida state summary report titled "Readiness for College." The study analyzed the performance of 1999 Florida public high school graduates on entry-level college placement tests in the 1999-2000 academic year. It revealed that in Miami-Dade County $59.2 \%$ of public high school graduates who entered a community college in Florida failed the mathematics part of the college placement test, while $51.5 \%$ failed the reading test, and $41.1 \%$ failed the English test. Only $27.8 \%$ passed all three of the college placement tests. The great majority of these underprepared high school graduates who continue into college studies enroll at Miami Dade College (Florida Department of Education, 2001). It may be that their lack of preparation is causing students to come up 
against "stopping points"; that is, required courses that they characteristically fail because of their lack of preparation for taking these courses.

Stopping Points

In March of 2001, Miami Dade College (MDC) examined required courses in the curriculum in order to identify "stopping points". The investigation revealed that at least 6 out of 10 of the stopping points that were keeping students from completing their degrees were mathematics courses. Community colleges offer college preparatory mathematics courses designed for students who arrive at college underprepared to take college level mathematics courses. As serious an obstacle as academic level mathematics courses present to the average community college student, it is college preparatory mathematics courses that have the highest proportion of students failing to complete the requirements.

Roots of Student Difficulties in Developmental Mathematics Courses

One of the causes of students' difficulties in college preparatory classes is that they contain material that students have already studied unsuccessfully in high school. People tend to avoid situations in which they have previously failed. Tollefson (1979) demonstrated how past experiences resulted in avoidance behavior among college students. The studies by Demitroff (1974) and Ramist (1981) pointed out how poor study habits contributed to this avoidance behavior, and this phenomenon was demonstrated among underprepared mathematics students by Paulos (1988). Tuckman (1990) developed his "procrastination scale" to measure and study the phenomenon. This is noteworthy since Bliss and Mueller (1993) found the management of time while 
preparing for academic tasks to be an important set of study behaviors that correlated highly with academic achievement.

When mathematics skills and knowledge that students failed to learn in high school are taught again in college preparatory classes at community colleges, students tend to try to avoid these situations connected to previous failures and often fail to engage. This reluctance to engage in mathematics classes is often described as "math avoidance" and manifests itself as an unwillingness to take the prescribed mathematics courses. Students wishing to graduate may put mathematics off until they are unavoidable. Students who come into Florida community colleges at the lowest level of mathematics prescribed by the placement test (CPT) must complete MAT 0002, MAT 0020/MAT 0024, MAT 1033, and MAC 1105 to obtain an Associate of Arts degree. Students are placed in MAT 0020 or MAT 0024 based on their scores. The MAT 0020 course contains a combination of computation and basic algebra skills (scores 30-64), while MAT 0024 course focuses more exclusively on algebra skills (scores $65-120$ ). The longer these four courses are put off, the more distant the prospect of graduation becomes. Avoidance behavior in signing up for and participating actively in these required mathematics courses results in obstacles to graduation from an associate degree program.

Participation in class may well be affected because these students' math avoidance may be accompanied by an emotion that has been called "math anxiety" Tobias (1993). Mathematics anxiety is a state of fear or tension that interrupts or blocks the mathematics learning process when the student can no longer avoid taking mathematics classes. The math anxious and avoidant student has difficulty doing well in 
mathematics because this individual avoids and delays mathematics courses, and puts off completion of tasks once registered in these courses (Paulos, 1988).

Looked at from a slightly different angle, a student's failure to perform as well in mathematics as he/she is capable of appears to be related to the psychological variables of low-self-esteem/self-efficacy (Solomon \& Rothblum, 1984). This is especially evident with students come to the college with low levels of basic skills in mathematics; students who have to take two or three college prep mathematics courses before enrolling in college level algebra. Their lack of a positive attitude towards learning mathematics is partially due to a low sense of self-efficacy and self-esteem, creating mathematics avoidance. This math avoidance is so common among students at MDC North Campus that some of them complete all courses in their programs except for mathematics, and never graduate.

The second cause of difficulty is common to all college students, and consists of the inherently abstract nature of mathematics. In order to succeed in mathematics courses students must be able to discover an abstract pattern, and then to generate the solution to a problem that can be solved through this pattern. However, according to Sutherland (1982) and Shayer, Kuchemann, and Wylan (1976), it should not be assumed that all adults can think in abstract ways. Community college students still locked into formal operational thinking typically have great difficulty with the abstract thinking needed to be successful in college level mathematics courses.

A third difficulty facing students taking college preparatory courses is the large amount of content in each of these courses that must be learned in a short period of time. For instance, for students who test into college preparatory mathematics courses at Miami 
Dade College, the progress required to succeed in any one level of college preparatory mathematics (one semester) is the equivalent of two full years of basic skills. This presents a great challenge to students in these courses who have had difficulty in mathematics courses taught at a more leisurely pace.

\section{Mathematics Course Progression}

An institutional research study investigating mathematics course progression rates at MDC analyzed the fall to spring progression rates in college preparatory mathematics courses for academic year 2001-2002. That study found that just $70 \%$ of the students who successfully passed MAT 0002 (the lowest level developmental mathematics course) registered for MAT 0024 (the next course in their sequence). Then only $75 \%$ of students who passed MAT 0020 or MAT 0024 registered for MAT 1033 (pre-algebra). Finally only $68 \%$ of students who passed MAT 1033 registered for MAC 1105 (college algebra).

These statistics also reflected the fact that the progression rate of students successfully passing MAT 0024 into MAC 1105 during the 2001-2002 academic year was only $36 \%$. This meant that approximately $64 \%$ of the total number of students who completed MAT 0024 did not complete the prerequisite course MAT 1033, that would have enabled them to register for MAC 1105 (the first college level mathematics course), within one year.

This was an important finding since based on data compiled and analyzed by the Institutional Research Department at Miami Dade College, students who disrupt the mathematics progression are less likely to earn a degree than students who follow the mathematics class sequence (MDC Institutional Research, 2003). For that reason, student services and academic affairs departments always recommend college prep mathematics 
students to continue the mathematics sequence (without skipping semesters in between) because they will be more successful if they do not disrupt the mathematics learning process.

\section{Mathematics Course Failure Rates}

The second part of this MDC Institutional Research study was concerned with the failure rates for students who registered into MAT 0024, MAT 1033, and MAC 1105. When analyzing the 2001-2002 academic year failure rates of students, it was found that only $38 \%$ of those who registered for MAT 0024 passed the course. This same study showed that only $47 \%$ of students passed MAT 1033, and only 57\% passed MAC 1105 .

These data showed just $10 \%$ of students who entered the college underprepared to take college mathematics courses successfully progressed from MAT 0024 through MAC 1105. This massive failure rate among college preparatory students is very alarming for the institution as well as for those failing students, because students tend to get discouraged and leave the institution, or complete all of their non-mathematics requirements, but not graduate.

The College Level Academic Skills Test

Another aspect of institutional research at Miami Dade College focused on the College Level Academic Skills Test (CLAST) results for MDC students who took the test in the period between the period of November 1, 2000 and February 29, 2001. This part of the study revealed that these students were least successful on the mathematics subtest. Only $38 \%$ of these students passed. Students must pass all sections of the CLAST before they can transfer to a 4-year public university in Florida with an Associate of Arts degree. That means that $62 \%$ of Associates in Art program students at MDC taking this part of 
the test could not transfer to an upper division university until this CLAST "stopping point" was resolved. Institutional Research (2003) has revealed that many of these students who have not been able to pass the mathematics part of the CLAST test are the same students who have waited until the final semesters to take their mathematics courses. After trying to pass the CLAST for some time, some of these students give up and leave college without obtaining a degree because their fear of mathematics is an obstacle to their success.

It is clear from the information presented above that mathematics courses are themselves, or are related to, stopping points within the curriculum of community colleges. Further, students caught at one of these stopping points are more likely to leave the institution than students who move smoothly through them. The stopping points involve both avoidance of and low academic achievement in mathematics. It is also clear that current developmental (i.e., remedial) mathematics courses designed to help underprepared students to be successful in college level mathematics courses are not particularly successful.

It follows, therefore, that developing new strategies that help students to achieve in college preparatory and college level mathematics courses should go a long way in helping students smoothly navigate stopping points and result in their being more likely to earn associate degrees at community colleges. One of these strategies could be the inclusion of instruction in appropriate study behaviors as part of the college preparatory mathematics courses. 
The somewhat intuitive relationship between the use of appropriate study behaviors and academic achievement was found by Bliss and Mueller (1987) in their work on the measurement of study behaviors and has been corroborated by Bliss and Sandiford (2002), Gersten (1998), and Pressley and Afflerbach (1995) among others. In describing the notion of study behaviors, Bliss and Mueller noted that there is often some confusion between the terms "study skills" and "study behaviors." They distinguished between them in the following way.

Study skills are the potentials for action while study behaviors are the observed actions, themselves. A student may have all the skills required, that is he or she may be able to take good notes in class (possession of a study skill) but simply sits in class doodling (the lack of a study behavior). This distinction is not trivial. Students are often placed in college and university developmental education programs because it is assumed, based on high school grades, admissions tests, and placement tests given at the time that they do not exhibit appropriate study behaviors (i.e., they do not take adequate notes; they do not use the library efficiently; they do not use study time well) and a large component of these programs are activities designed to develop skills such as note taking skills, library use strategies, and time management ability. It is assumed that students do not exhibit study behaviors because they do not possess the appropriate study skills. This assumption may often be unjustified. $(1987$, p.16)

While it must be noted that there is evidence of a positive relationship between academic achievement and the use of appropriate study behaviors, this correlation is not evidence of a causal relationship between these two variables. It should also be noted, however, that such a correlation is a necessary, but not sufficient, requirement for suggesting that there is a causal relationship between two variables. More recently, studies such as those by Bender (1997); Sagher and Siadat (1997); Stallworth-Clark, Nolen, Warkentin, and Scott (2000); and Tuckman (2001) have looked at this relationship 
and found differences in achievement between students who received training in the use of appropriate study habits and those who did not. However, these studies tended to be ex post facto and use single group designs that left much to be desired in terms of controls.

Therefore, while the relationship between study behaviors and academic achievement in college and university students has been well established, the possibility of a causal relationship between these two variables is still being investigated. How useful the uncovering of any causal relationship between these two variables will be in terms of academic program design, however, will hinge on the question of whether the use of appropriate study behaviors can be taught to students. This research project was undertaken to investigate this relationship.

\section{Teaching Appropriate Study Behaviors}

Put quite simply, any relationship, whether causal or not, between academic achievement and the use of appropriate study behaviors will be of very limited use to educators unless it is possible to change the level of students' use of these behaviors. Should it prove impossible to teach students to use more appropriate study behaviors, the observed relationship would be, at best, only useful in identifying students who are at risk for academic difficulties and who might, therefore, be likely to drop out of their programs. This would be much more useful, however, only if there were some intervention that could be used to remediate the problem.

Recent work by a number of investigators including Elliot, Foster, and Stinson, 2002; Gettinger and Seibert (2002); and Horner and Shwery (2002) have demonstrated that appropriate study behaviors and other self-regulatory behaviors can be taught both to 
high school and post-secondary students. This can be done using a variety of instructional strategies that include modeling, metacognitive activities, and direct instruction that can be taught as self-standing activities or can be integrated into other learning activities.

Cognitive modeling. Cognitive modeling teaches students to solve problems by exposing the students to the expert's normally covert cognitive processes. In other words, students are shown how to embrace the expert's way of thinking (Gorrell \& Capron, 1990). Research on cognitive modeling has shown that poorly performing mathematics students have benefited from cognitive modeling and guided performance because the covert problem solving process is made observable by providing modeling and explanations of the processes, creating an increase in students' performance (Schunk, 1981; Welkowitz \& Calkins, 1984). When students are presented with modeling, corrective feedback, performance guidance, and instruction in how to engage in selfdirected mastery, their self-efficacy rises and skills development is encouraged (Bandura, 1977).

Meta-cognition. Meta-cognition has been defined by Brown, (1987) as the knowledge about operations of cognition and how to use them to achieve learning goals. A more explicit definition by Ormrod (2000) defines meta-cognition as students' knowledge and beliefs regarding their own cognitive processes as well as their attempts to regulate their cognitive processes to maximize learning and memory. Ormrod writes that knowing how to study is a skill that must be taught to students. She listed several effective meta-cognitive study strategies such as monitoring comprehension, 
summarizing, note taking, having good organization skills, identifying important information, retrieving prior knowledge, and being motivated. These study strategies can enhance cognitive processing, thereby increasing students' academic performance.

Research has shown that students can be taught to enhance their academic performance using meta-cognitive strategies (Pintrich \& DeGroot, 1990). The more information students have in reference to effective learning strategies, the greater their meta-cognition awareness will be (Perkins, 1995). If a student with poor academic performance is aware of how he/she learns and how to control the learning process, this student can improve academically (Zimmerman, 1995).

\section{Study Behaviors Interventions}

In a study by Cone and Owens (1991), a multi-test orientation inventory was administered to 250 first year students. The investigation showed that students who attended a study skills course performed better academically. As a result of their study, the researchers suggested that a first year study skills course could improve academic achievement among students.

Bliss and Mueller (1987) pointed out that college students who are placed in college preparatory courses often do not demonstrate appropriate study behaviors. As a result of their research, they recommended that activities that teach study behaviors such as time management, note taking, and examination taking techniques should be given to students. In addition, they posited that a strong counseling component focusing on students' feelings of self worth and competence would be useful.

Another approach to teach students appropriate study behaviors is Supplemental Instruction (SI). This method, customarily used for mathematics and science courses, was 
developed at the University of Missouri in 1973. It is designed to improve academic performance by using a combination of cooperative and collaborative learning strategies (Martin, Lorton, Blanc \& Evans, 1977). The method assists students in integrating study skills and habits with the content of the class (Wolfe, 1987). According to the Center for Academic Success at the Louisiana State University, students participating in Supplemental Instruction earn higher mean final course grades than do students who do not participate in this program. Also, students involved in SI succeed and persist at a higher rate regardless of ethnicity and prior academic achievement (Louisiana State University, 2006).

Research indicates that instruction in the process of solving mathematics problems, together with actual practice and repetition of solving these problems, is the most effective method of resolving math avoidance and math anxiety difficulties. In this study, students will be taking a course to learn study behaviors and the process of solving mathematics problems. The students will be encouraged to apply appropriate study behaviors in their mathematics class and lab by instructors who model these behaviors. These modeling and self-regulatory activities will influence students' cognition by creating learners who are aware of their weaknesses and strengths. In order to measure the effect of these interventions, an instrument that quantifies these results is required. Measuring Study Behaviors

Wrens' Study Habits Inventory, published in 1941, was one of the early measurements of study habits and study skills. He maintained that if ability was controlled for, study habits could predict academic success of students. Other researchers added to the work initiated by Wren. Brown and Holtzman (1966) developed the Survey 
of Study Habits and Attitudes (SSHA). The SSHA measured students' study methods, their motivation for studying, and their attitudes toward scholastic activities. The need for a standardized version of the SSHA for the purpose of diagnosing and counseling college students resulted in the creation of a revised edition called SSHA Form C (Brown, 1972).

Another assessment tool used by researchers to measure study behaviors is the Learning and Study Strategies Inventory (LASSI). This instrument was developed by Claire Weinstein at the University of Texas, and was designed to measure college students' cognitive and affective growth after completing a study strategies course (Weinstein, Schulte, \& Palmer, 1987). LASSI provides standardized scores and national norms for ten different scales. The test concentrates on both covert and overt thoughts, behaviors, attitudes and beliefs that facilitate successful learning. It is a diagnostic and prescriptive test that provides students with a diagnosis of their weaknesses and strengths and also provides feedback on how to improve attitudes and behaviors.

In 1982, Mueller and Gibson developed the first form of the Study Behavior Inventory (SBI). This instrument was inspired by the work done by Wren (1941) and Brown and Holtzman, (1966). In 1983, the Study Behavior Inventory, Form C was developed by expanding the number of items related to test anxiety and coping behavior (Muller \& Gibson, 1983). The most recent version of the Study Behavior Inventory (Form D) was developed by Bliss and Mueller in 1986. In a study they conducted (Bliss \& Mueller, 1987), factor analysis revealed three underlying factors dealing with feelings of competence as a student; time management in the preparation for day-to-day, routine academic tasks; and time management for longer-term and special academic tasks. The 
instrument demonstrated a high level of predictive validity for grade point average and good internal consistency reliability within each of the three factors.

For these reasons, this study used the Study Behavior Inventory, Form D, as a measure of students' study behaviors. This allowed the testing of the effect of instruction on students' use of these self-regulatory behaviors.

\section{Significance of the Study}

There is a wealth of evidence in the literature on studying and study behaviors that supports the idea that there is a relationship between how students study and their academic achievement. While the idea that effective studying results in higher academic achievements is very intuitively comfortable, there is little evidence that this particular relationship actually exists since most studies in this area are correlational with a sprinkling here and there of ex post facto research designs. This study was undertaken to provide evidence, using an experimental design, for a cause and effect relationship between these two variables. Since the effort required the implementation of a strategy to teach students to use appropriate study behaviors, the study also seeks to demonstrate the efficacy of such a teaching strategy. If teaching strategies could be developed to help students study more effectively and if these strategies resulted in higher academic achievement, there is sufficient theoretical grounding to claim that the probability of these students dropping out of community college would decrease. This would be of value both to the students and to the society in which they live.

\section{Delimitations of the Study}

1. This study was concerned only with students in college preparatory classes who are taking developmental mathematics courses. 
2. This study was conducted in a multi-campus, multi-cultural urban community college with a non-traditional population.

\section{Summary}

Nowadays, more students are entering higher education institutions inadequately prepared to successfully complete college and university level courses. Although many of these students are enrolled in developmental courses designed to provide them with the necessary tools to succeed in college, these developmental programs have not been very successful (National Center for Education Statistics, 2002).

The purpose of this study is to investigate if there is a causal relationship between study behavior and academic achievement, and whether the use of the appropriate study behavior can be taught to college students. This study is designed to determine the efficacy of an intervention intended to increase the frequencies of appropriate study behaviors on the part of community college students who were placed into developmental mathematics. In addition, it will determine whether this increase in appropriate study behavior frequency is accompanied by increased academic achievement in developmental mathematics courses as measured by course grades. Mathematics was chosen because research has shown that it is the subject area with which students have the greatest difficulty.

Studies have been done to understand why mathematics is a barrier to success for college students, and a number of them indicate that deficiency in study behaviors and skills preclude these developmental students from achieving their academic goals (FaroSchroeder, 1995; Morris, 2003). Research studies done by Nokes and Ohlsson (2001) and by Tobias (1993) suggest a relationship between effective study behaviors and academic 
success. These studies concentrate on the inculcation and repetition of behaviors that have been shown to assist in learning abstract subject matter, such as mathematics.

Therefore, this study was undertaken with the assumption that improvements in college students' study behaviors might well result in higher success rates in the required basic skill courses and ultimately, a higher retention rate. The next chapter presents a review of the relevant literature on student retention, study behaviors, and teaching study behaviors. 


\section{CHAPTER II}

\section{LITERATURE REVIEW}

This study investigates the effect of instruction in and performance of appropriate study behaviors among college preparatory math students in order to determine if there is evidence to suggest that there is a cause and effect relationship between appropriate study behaviors and the level of achievement of community college students in remedial mathematics courses. The study was done at a multicultural, multiethnic, urban community college; undertaken to contribute to the existing literature on the topics of study behavior, study skills and retention of community college students. Chapter 2 contains a review of relevant literature in order to address the study's theoretical background.

\section{Student Retention: A Problem at Community Colleges}

Winston and Sandor (1998) stated, "With college enrollment declining and college populations changing... retention has become a key issue that affects the success of the institution" (p.15). Community colleges around the nation have had an attrition rate almost three times the rate at 4-year institutions in the first year of college and almost twice that of 4-year public institutions in the second year of college enrollment (National Center for Education Statistics, 2002). This differential has been recognized for some time, but a fully satisfactory theoretical explanation has not yet been provided.

Theoretical models of student attrition from 4-year colleges have served as the foundation for retention theories recognized in higher education (Astin, 1975, 1977, 1985, 1993; Cabrera, Castaneda, \& Nora, 1993; Cabrera, Castaneda, Nora, \& Hengstler, 1992; Farabough-Dorkins, 1991; Pascarella, 1986; Pascarella \& Terenzini, 
1998; Spady, 1970; Tinto, 1975, 1993, 1998). Spady's work on student attrition;

Tinto's model describing the student's academic and social integration; Cabrera, Castaneda, Nora, and Hengstler's model of student integration; Astin's student involvement theory; and Pascarella and Terenzini's work on the psychological and cognitive development of students have provided the theoretical foundation for the most commonly accepted model that explains attrition in higher education. The focus of this model is on institutional factors, and in particular on an institution's ability to provide a sense of belonging to its students. However, these theories do not focus on the likelihood that the study skills and behaviors that characterize the community college student population are not the same as those of the university student population, where these commonly accepted retention theories were developed (Hrabowski, 2003).

The lack of an adequate theory to explain attrition rates in community colleges likely developed because retention theories have been formed from research done on mostly white, residential, full-time late adolescent students attending 4-year institutions (Pascarella \& Terenzini, 1998). The community college student population does not fit this profile. For example, since a growing proportion of students in community colleges in the United States are adults, Tinto's 1975 psychologically oriented model of Student Integration is not consistent with the reality of adult students who commute to and from work and school. In an attempt to explain the attrition pattern of adult students, Bean and Metzner $(1985,1987)$ developed the Student Attrition Model. This model added to Tinto's theory by including variables from the external environment, suggesting that when it came to attrition, strong 
environmental variables could counterbalance weak social interaction or academic performance (Bean \& Metzner, 1985, 1987). Another model presented by Cabrera and associates $(1992,1993)$ combined elements from the Student Integration and Student Attrition models and also included external environment variables. A third well known model proposed to incorporate theories of adult development into the established theories of student integration to their institution. This model is known as the Adult Persistence in Learning (APIL), and it assesses factors that affect the academic persistence of adult students (McKinnon-Slanery, 1994).

Secondly, due to the deficiencies in study behaviors that characterize many 2year college students, Tinto's psychological model of social integration into a traditional academic institution may be inadequate to explain their high rate of attrition (Faro-Schroeder, 1995). Tinto's Student Integration model does show promise in community colleges that design interventions based on this psychological model. For example, the Student Life Skills (SLS) courses at Miami Dade College use this approach for first semester students who score low on components of the institution's Computerized Placement Test. Although some positive retention results have been documented from such interventions, since study behavior is not part of the class curriculum, it is not clear that they address the fundamental problem of weak study behaviors. Consequently there is little evidence that interventions using the student integration model alone will increase the graduation rates of students at MDC or in similar institutions (Morris, 2003).

It is also worth noting that while an abundance of research has been done on student retention and the predictors of success at 4-year institutions, few studies have 
been conducted in a multi-campus, multicultural urban community college, where the student population is comprised primarily of part-time, racial/ethnic minority, and older students, who are typically characterized by deficiencies in academic basic skills, especially in math (Boylan, 1999). Recent work done by the Roaches at the University of Texas proposes to set up an electronic clearinghouse of studies focusing on community college attrition; but even those community college attrition studies refer to findings concerning primarily full-time students. As with the work on 4-year college students, fundamental assumptions are that engagement with the institution is a more important factor than the level of study behavior and study skills that students bring to the institution (Roueche \& Roueche, 1993). However, these community colleges show an especially high failure rate of students in the required mathematics courses, and it may well be because of poor study habits.

Academic Success: Bandura's Social Cognitive Theory

By their nature, study habits concern behaviors. Bandura's Social Cognitive Theory is frequently used as the theoretical grounding for explaining students' behavior and academic achievement. This theory emanates from Social Learning Theory, and focuses on predicting and understanding individual and group behavior. It accounts for the intricacy of interaction between beliefs, behavior, and environment. It also identifies methods to transform or modify behavior (Bandura, 1989).

Bandura (1977, 1986, 1989), has identified human behavior as a triadic, dynamic, and reciprocal interaction of behavior, the environment, and personal factors. In his theory, behavioral factors are identified as the personal options the individual engages in that influence the individual and his or her environment. The environmental factors are 
the situations that individuals find around themselves influencing them and their behavior, and personal factors are beliefs, which impact the individual and his/her behavior. Based on his research, Bandura concluded (a) that effective individuals are in control of their behaviors, their environment, and their thoughts and (b) that the environment can be modified through behavior. The ability to control behavior and the environment has an effect on the individual's success (Gredler \& Schwartz, 1997; Miller, Behrens, Greene, \& Newman, 1993). The psychological variable that measures one's confidence in controlling one's behavior and environment is called self-efficacy. Followers of Social Cognitive Theory support the idea that self efficacy is a crucial variable affecting self-regulated study behavior and learning, and researchers have determined that students' self-efficacy perceptions are related to their use of learning strategies and self monitoring (Bandura, 1997; Zimmerman, 1989, 1995).

The ability to take control of one's learning, including changing aspects of one's behavior, is referred to by Zimmerman (1994) as regulation or self regulatory learning. Behavioral self-regulatory strategies in academia are those behaviors the student engages in to promote academic goals, for example, reviewing class notes, checking work before turning it in, or reviewing possible test questions. A result of self-regulated behavior is that a student who can self regulate typically finds a way to learn the material. It is not that significant if the chapters in the book are confusing, the instructor is mediocre, the exam is hard, or if several exams are scheduled for the same day or week, a self-regulated student finds a way to accomplish his/her goals successfully.

Researchers use Social Cognitive Theory to explain learning and behavior. This theory provides an explanation of self-regulated study behaviors, learning goal 
orientation, performance goal orientation, levels of self-efficacy, perceived future consequences, and persistence behaviors (Bandura, 1997; Schunk, 1996; Zimmerman, 1989). Each of these elements as defined under the Social Cognitive theoretic perspective will now be discussed.

\section{Self-Regulated Study Behavior}

Zimmerman (1989) has offered a framework for examining college student success, including student related and externally regulated categories, with an addition of a behavioral component (environmental and personal interaction). He stated that students' learning behaviors affect their environment through self-regulation, and that to meet the criteria of a self-regulated learner; students must use specific learning strategies to achieve academic objectives. A person is said to be a self-regulated learner when this individual establishes the most favorable conditions for learning and eliminates obstacles that obstruct his/her learning process. For instance, a student who believes in his/her efficacy for self-regulated learning has the tendency to set academic goals and reach higher levels of academic achievement.

More recently Simmons (1996) conducted a study designed to assess students' beliefs about the cause of academic failures, academic self-efficacy, orientation toward learning and performance goals, and use of study strategies. That study analyzed the beliefs and attitudes that low-achieving college students have about themselves as learners. The study was conducted with 100 low-achieving college students and 200 college students in good academic standing. Findings showed that learning goal orientation had the strongest effect on use of study strategies for both low achieving 
students and students in good academic standing. Results also demonstrated that for low achieving students, attributing failure to lack of effort was negatively related to their use of appropriate study strategies. On the other hand, the attribution of failure to ability was positively related to the use of good study strategies. Low-achieving students should be encouraged to put forth greater effort in order to become better self-regulators of their learning, which will in turn help them to be able to achieve academic success.

Subsequent studies have shown that when students self-regulate their learning strategies and their study skills, they tend to improve academically (Pressley \& WhartonMcDonald, 1997; Zimmerman, 1989). For instance, when a self-regulated learner has an exam, the person sets goals and an action plan delineating how to prepare for the exam, monitors her understanding of the required material when studying, uses a variety of learning strategies, takes breaks when his concentration is diminishing, changes the learning environment when it is distracting, and asks the instructor for assistance when needed.

\section{Goal Orientation}

Research done on goal orientation has identified two types - learning goals and performance goals (Ames, 1992; Ames \& Archer, 1988; Greene \& Miller, 1996). Learning goals refer to the command of a specific task or subject matter, while performance goals are displayed behaviors that show oneself to be competent and knowledgeable in front of peers.

A learning goal orientated student aims for the mastery of the content, while a performance goal oriented student promotes a shallow processing of information for the attainment of an immediate objective (Ames, 1992). A student who adopts learning a 
goal orientation has the tendency to invest more time and effort in learning new concepts and information, engages in the quest for knowledge, and has more challenging goals (Ames, 1992, Zimmerman \& Risemberg, 1997). The learning goal orientated student integrates self-regulated strategies to control behavioral, environmental, and personal factors. Also, this student persists in mastering the material when faced with difficulties much better than does a student who adopts performance goals. Research has shown that students who demonstrate learning goals perform better and show more efficacy than performance goal oriented students (Ames \& Archer, 1992).

Research has also shown that students who were learning goal oriented were more interested in understanding relevant information and gained more in-depth knowledge of the content matter (Nolen, 1988). In short, a learning goal orientation is positively related to academic performance (Zimmerman \& Risemberg, 1997).

\section{Self-Efficacy}

Self-efficacy has been described as one's perceived ability to accomplish a specific task. It is related to and predictive of behavior (Bandura, 1997). There is much information available on the relationships between self-efficacy and persistence, and on their interrelation with performance. Different studies (e.g., Multon, Brown, \& Lent, 1991; Vispoel \& Chen, 1990) have demonstrated a relationship between levels of selfefficacy and performance in classes. Not surprisingly, according to Bandura (1986, 1997), self-efficacy has been found to be predictive of academic achievement. As an example of this, a study that was conducted with 42 education majors enrolled in an upper division undergraduate psychology course described a theoretical model of the components of academic studying that focused on antecedents to as well as on the 
consequences of studying. The researchers used correlational means to investigate the relationship among student characteristics, study activities, and academic outcomes. That study showed that self efficacy is significantly related to cognitive processing initiative, and test performance, and that academic self-efficacy and internal consistency of students' knowledge structures were significantly predictive of classroom achievement. It was also found that self efficacy positively correlated with study behaviors and had a significant impact on study activity engagement (Warkentin, Griffin, \& Bates, 1994).

Reflecting Social Cognitive Theory's emphasis on the importance of an individual's feelings of self efficacy, a study analyzing self-reported study behaviors, test anxiety, and past achievements revealed that students' past achievement explained the largest proportion of the variance. Additionally, self regulatory study behaviors (using the teacher as a resource person and using formative evaluation procedures) yielded significant partial correlations (Tollefson et al., 1979).

Concerning self-efficacy specifically in mathematics, Dweck and Leggett (1988) and Weiner (1979) have pointed out that students who believe that they do not posses mathematical abilities tend to be uncertain about their math performance and show a low level of self-efficacy and competence in math. This low level of self-efficacy and competence in math also is related to and may affect their motivation to study and master math skills. In a related vein, Tuckman (1990) conducted a study on self-esteem and feelings of competence concerning information processing activities with 183 college junior and senior students. Three different instruments were administered to these students: The Schrerer Madux General Self-Efficacy Scale, an inventory that measures self-reported student performance, and the Tuckman Procrastination Scale. This last 
instrument, developed by Tuckman, measures self-reported, self-initiated study by college students as related to self-efficacy (e.g., delay, avoid, blame). Results revealed that college students who reported putting off work until deadlines were due or wasting time also exhibited low levels of self-efficacy. These students demonstrated less effort and doubted their ability more than students who did not procrastinate.

Research has shown that when self-efficacy is low, the students give up relatively easily by avoiding tasks or putting them off. Students who show low self-efficacy have low self-esteem and have a lack of self-motivation to perform the work. It has been proven that low self-efficacy undermines performance. Students with low self-efficacy emphasize previous failures instead of designing problem solving strategies (Bandura, 1997; Zimmerman, 1989).

Perceived Future Consequences and Persistence Behaviors

Perceptions concerning future consequence are also related to self-efficacy and academic achievement (Bandura, 1997). In a study conducted at the University of Connecticut, 386 community college students were administered a survey to find out if their self-efficacy levels in study skills, learning/performance goal orientation, perceived future consequences, and persistence were related to their GPAs. The study demonstrated that study skills, self-efficacy and persistence have a direct positive relationship to grade point average and future consequences, and performance goal orientation has an indirect relationship to GPA. These findings contributed to educators' understanding of academic achievement and how self-efficacy is related to self-regulated study behaviors, perceived future consequence, goal orientation, and persistence (Silver, 1999). 
Another study, that investigated reasons for successful and unsuccessful performance by first year and upper level university students, asked 117 undeclared major and business major students to describe a specific situation when they were successful (productive) or unsuccessful (unproductive) in a class. The subjects of the study explained why they thought they succeeded or failed and who was responsible for the success or failure. The study revealed that $29 \%$ of students reported that studying for assignments and exams, and persistence led to academic success, $27 \%$ said that setting appropriate goals made them successful, and $32 \%$ reported that they failed because they did not study. This study showed that students believed that their study habits play a role in academic success (Schmelzer, Schmelzer, Figler, \& Brozo, 1987).

Study Behavior and Academic Achievement

Research has shown that study behaviors account for more variance in measures of learning achievement than do the SAT/ACT scores, or high school grades and class ranking (Bliss \& Mueller, 1993; Hunter, 1979). Also, study habit inventory scores contribute more variance in predicting academic success than ability aptitude tests alone. Researchers have linked good study habits to passing grades for both high school and college students. Students who have good study habits are more likely to pass their courses and persist in college, while students who have poor study habits more often fail courses and subsequently drop out of college (Demitroff, 1974; Ramist, 1981).

That is not to say that the identical study skills are called for in both school settings. An appraisal of scores on study methods inventories conducted by Thompson (1977) looked at the environmental difference between high school and college and the need for independent study for students to excel academically at the latter. It concluded 
that students most likely to succeed exhibited better study habits and adapted better to college's academic norms and requirements than students who lacked good study habits. Also students with good study habits were more self-reliant, and academically oriented.

Another study that correlated academic achievement with study behaviors was done by Stewart (1984). He investigated study skills including the length of time spent in study by 50 college undergraduate educational psychology students. A questionnaire was given to these students to identify their study habits prior to each class exam. Results showed that total hours of study and type of study behavior strategies employed were positively related to students' grades. An earlier study that specifically examined study skills and mathematics achievement among 46 first-year mathematics students also revealed that the distribution and length of study time is a factor of considerable importance in mathematics achievement (Poulsen, 1975).

In yet another study, study habits including time management were documented as the major problem facing beginning college students (Thombs, 1995). That study selected first semester freshmen students who did not meet academic standards for regular admission. The students were evaluated as to their time management skills, relations with faculty, control of alcohol use, and avoidance of general self-defeating behaviors.

Survey of Study Habits and Attitudes

A number of small scale studies used the Survey of Study Habits and Attitudes (SSHA) as one of the instruments administered to students to analyze relationships between their study behaviors and academic success. The first study compared low GPA 
students to higher GPA students at Rockland Community College using five constructs: study habits and attitudes, motivational factors, reading ability, career decisiveness, and learning styles. The SSHA, the Personality Research Form, the Diagnostic Test for Language Skills, the Career Decision Scale, and the Learning Styles Inventory were completed by 19 students in academic difficulty and 31 students not in academic difficulty. The study showed that academic difficulty was most closely associated with study habits and attitudes, reading comprehension skills, and expectations for academic success (Judd et al., 1985).

The second study investigated the relationship between at-risk college students' study habits and academic performance using the SSHA and the Problem Solving Inventory (PSI). Sixty-three at-risk students took the survey that measured personal control, problem-solving confidence and approach-avoidance behavior. Statistical analysis showed that students' self-appraisal of their ability was positively related to their study habits identified by the SSHA. These students appeared to be aware of their deficiencies in study behaviors and open to interventions that could improve their performance (Elliott, Godshall, Shrout, \& Witty, 1990).

Finally, the SSHA was mailed to a randomly selected sample of $10 \%$ of the fulltime student population at York College of Pennsylvania. The purpose of the study was to investigate if students' study habits and attitudes had an effect on their grade point average. Only 40 usable responses were matched in the study. The study determined that a significant correlation existed between SSHA scores and student GPA. Based on this research, a developmental course to teach study skills was created at the college (Pierog, 1976). 
Three studies using the Study Behavior Inventory-Form D (SBI-D) were conducted at community and 4-year colleges with the purpose of investigating study behaviors that have been shown to affect academic achievement. One study was done at American River College and Sacramento City College in California. A total of 1,441 students registered in English and Psychology classes participated in a study to determine the correlational values among the variables of test anxiety and study behavior, taking into consideration age, gender, and ethnicity. The SBI-D and the Sarason's Test Anxiety Scale (TAS) were administered. That study revealed that the best predictor of higher levels of test anxiety was lower levels of study behavior skills (Rasor \& Rasor, 1998).

A second study administered The Study Behavior Inventory-Form D to 74 science students at Wilson County Technical College in North Carolina to assess their study skills and habits. The study showed that a number of students had difficulty with time management and keeping up-to-date with assignments. In addition, difficulty with reading, note-taking skills and test anxiety were also noted (Kuhn, 1988).

A third study that identified the study behaviors of 322 Spanish-speaking students was conducted at Miami Dade College. This study used El Inventario de Comportamiento de Estudio (ICE) developed by Bliss, Vinay, and Koenigner (1996). This instrument is the Spanish version of the SBI-D. That study showed that academic self-efficacy was the factor that accounted for the most variance, and that high selfefficacy students were more concerned than students with low self-efficacy about longterm study behaviors and the need to manage time over the long run (Bliss \& Sandiford, 2002). 
In conclusion, there is considerable empirical evidence that supports Social Cognitive Theory's focus on the interaction between people's beliefs, behaviors, and environment. Relatedly, the research presented here further points to the fact that possessing good study skills and study habits has been correlated with good grades and persistence in college. In addition, as the following section demonstrates, there is evidence that more effective study behavior can be taught.

Improved Study Behaviors and Increased Academic Achievement Some of that evidence comes from the review of research concerning contributions of study skills to high school and college academic success conducted by Gettinger and Seibert (2002). Further evidence comes from Horner and Shwery's (2002) study of summer reading program for elementary school where the children were taught how to become better, more self regulated readers. In addition, Elliot, Foster, and Stinson (2002) conducted a small scale study with high school and college hearing impaired students and their teachers. It is worth noting here that these researchers all found that appropriate study behaviors and other self-regulatory behaviors can be taught to students by using instructional strategies such as modeling, metacognitive activities, and direct instruction. Modeling is when a student is exposed to explicit training in a specific metacognitive strategy. The student will observe and compare his/her own performance with that of the model and modify weak learning approaches Model-eliciting activities provide students with an opportunity to use metacognitive functions such as reflection, planning, monitoring, and control (Lin, 2001).

Metacongition is defined as knowledge about cognition (knowing what you know) and knowledge about regulating cognition (knowing how you know). It can be 
explained as thinking about one's own thinking or the knowledge and control a student has over his/her own thinking and learning activities (Flavell, 1979). Metacognition activities influence cognition by creating students who are aware of their strengths and weaknesses and work towards remedying their weaknesses.

Direct Instruction (DI) is a specific model of instruction within a larger category of teacher-directed instruction. According to Martin, Lorton, Blanc, and Evans (1977), DI is a fast-paced teaching method that provides constant interaction between students and teachers. Its goal is to accelerate learning by maximizing efficiency in the design and delivery of instruction. The method emphasizes structured lessons, drilling, and content. DI is designed to teach from basic skills to higher order constructs such as deductive and inductive reasoning.

One study finding that study behaviors can be taught that is particularly germane to the present study is a small-scale study of a 4-week summer intervention program for disadvantaged pre-health science students, was conducted in West Virginia by Haught (1996). In that study, 16 economically disadvantaged pre-medicine or predentistry students were selected as the experimental group and another 16 premedicine or pre-dentistry students who were not categorized as disadvantaged were selected as the control group. The students were tested on the Nelson-Denny Reading Test in writing, study skills, biology, math, and chemistry. In addition, the experimental group completed the Learning and Study Strategies Inventory (LASSI) and the Perceptions, Expectations, Emotions, and Knowledge About College (PEEK) instruments. The intervention program taught students effective metacognitive strategies for reading and learning study skill (e.g., note taking, textbook reading, 
organizational and time management skills, and test taking skills). This study revealed that the students from the experimental group who completed the 4-week intervention program scored significantly higher when the LASSI was given to them again at the end of the program. The experimental group reported that they managed time more effectively, processed important information while studying better, were less anxious about school performance and tests, were better able to concentrate on tasks, and to recognize and select main ideas than before the intervention occurred. In addition, it should be noted that they were considered more academically successful than the control group because they attempted and earned more credit hours.

Further, Gillis and Olson (1989) using the SSHA analyzed learning behavior and its correlation on course content knowledge on undergraduate students at a central Texas university. One hundred twenty two education majors enrolled in four sections of a freshman level course participated in this study. The four sections were randomly selected to either serve as the experimental or control groups. Treatment Group One had learning strategies integrated with course content. Treatment Group Two was taught only the same course content. The third and fourth sections served as control groups, whose members worked in public schools as aides and were taught neither course content nor learning strategies.

Pre-test SSHA scores indicated no initial differences in study skills and habits among the four groups. Analysis of variance and covariance of post-test scores revealed that, the group receiving learning metacognitive study strategies with content instruction reported significantly better study habits and obtained better knowledge of the course material. These regular university students apparently benefited from learning about 
good study skills along with course content. That finding raises the question of whether or not this instructional strategy would likewise help a demographically different higher education population - developmental community college students.

\section{Student Retention: Helping Community College Students}

In many community colleges, the at-risk student is identified when the individual is placed on academic warning or academic probation due to a semester or two of poor grades. By that time, it is usually too late because these students typically leave the institution without seeking assistance (Holderman, 1995). Data from the National Center for Education Statistics (2002) indicate that the first year of attendance at a community college is the most critical for students' persistence in striving for their academic goals. It is clearly to the advantage of the institution to detect the at-risk students when they first start attending college, instead of when they are identified as failing to meet the institution's criteria for minimum academic progress required by each community college. This early detection can be improved by diagnosing study behaviors and using this as an additional predictor of success for new students (Roueche \& Roueche, 1993). By identifying likely non-persister students as soon as they start college, institutions have the opportunity to implement programs and strategies that provide instruction in and monitor repetition of appropriate study behaviors. Such programs may assist and increase the institution's retention, progress, and finally, graduation rates (Brittenham et al., 2003).

Several community college studies have been designed to identify likely factors that would help predict new students' success. According to Boylan (1999), low math grades correlate with low retention rates. Relatedly, a study conducted at Prince George's 
Community College in Maryland determined that math placement test scores were the most efficient method for detecting at-risk students (Boughan, 1995).

A final study that looked at community college students focused on those in developmental math (Brown, 1986). That study tried to identify factors predictive of persistence, success, and math achievement in a developmental arithmetic course at an urban community college. Study findings suggest that the academically diverse population of community college students requires effective interventions based on study skills and behaviors in order to improve persistence and success rates. In that study Brown concluded that low pre-test scores in math were significant predictors of attrition and lack of success among students at urban community colleges. However, he stated that an additional pre-test (e.g., Study Behavior Inventory) was needed to improve interventions for the diverse demographic and academic population of community college students.

In summary, all these studies demonstrate that teaching study habits has been shown to be correlated with student comprehension of course material. It is now time to document if this is more than a correlational relationship. This study intends to determine the efficacy of an intervention designed to increase the frequencies of appropriate study behaviors on the part of community college students. It is expected that improvements in study behaviors among underprepared math students can result in higher rates of success in gatekeeper math courses. Success in math has been shown in the long run to strongly affect retention rates (Boylan, 1999). 


\section{Purpose of This Study}

A number of studies that have investigated the causal relationship between the use of appropriate study behavior and academic achievement observed achievement differences between subjects who received training in the use of appropriate study habits and those who did not (Bender, 1997; Sagher \& Siadat, 1997; Stallworth-Clark, Nolen, Warkentin, \& Scott, 2000; Tuckman, 2001). But these studies were ex post facto and single group design projects that presented a problem in terms of controls. Several studies, for example those by Bliss and Mueller (1987), Bliss and Sandiford (2002), Gersten (1998), and by Pressley and Afflerbach (1995) have also stated that a relationship exists between the use of appropriate study behaviors and academic achievement, but this correlation is not sufficient evidence enough of a causal relationship between the two variables. Therefore this study was undertaken to ascertain the possibility of a causal relationship between the use of appropriate study behaviors and academic achievement.

The study was designed to demonstrate if a causational link exists between instruction in effective study behaviors and increased practice of these same behaviors that have been correlated to improved academic achievement. The objective was to establish if there existed a causational logic that leads from instruction, to practice of appropriate study behavior, to academic results.

\section{Summary}

In conclusion, since repeated studies have verified the strong correlation between effective study behaviors and student success, and since other studies have demonstrated that effective study behaviors can be inculcated, this research will experimentally 
determine whether a cause-effect relationship exists between effective study behaviors and student success. The hypotheses to be tested at the .05 level will be the following: Hypotheses for Research Question \#1

Hypothesis \#1: After one semester, preparatory math students who were instructed in the use of appropriate study behaviors will score higher on the academic the self-esteem factor of the Study Behavior Inventory than those who were not so instructed; after adjusting for the scores obtained at the beginning of the semester.

Hypothesis \#2: After one semester, preparatory math students who were instructed in the use of appropriate study behaviors will score higher on the preparation for everyday, routine academic tasks factor of the Study Behavior Inventory than those who were not so instructed; after adjusting for the scores obtained at the beginning of the semester.

Hypothesis \#3: After one semester, preparatory math students who were instructed in the use of appropriate study behaviors will score higher on the preparation for unique, long range academic tasks factor of the Study Behavior Inventory than those who were not so instructed; after adjusting for the scores obtained at the beginning of the semester.

Hypothesis for Research Question \#2

Hypothesis \#4: After one semester, preparatory math students who were instructed in the use of appropriate study behaviors will have higher final course grades than those who were not so instructed; after adjusting for the scores they obtained on the Computerized Placement Test. 


\section{CHAPTER III}

\section{METHODS}

This study proposed to investigate if there is a causal relationship between study behavior and academic achievement, and whether the use of appropriate study behavior can be taught to college preparatory students attending a multicultural, multiethnic, urban community college. The findings will augment the existing literature related to study behavior, study skills, and retention of community college students. Such a relationship could be used to design interventions to improve success rates of remedial-level math students in Associate in Arts and Associate in Science degree programs at community colleges.

Subjects

At the time of the study Miami Dade College (MDC) was a six-campus, publicly supported institution, serving the multiethnic and multicultural communities of MiamiDade County and adjoining areas of Southeast Florida. The college currently enrolls the largest number of students in any postsecondary institution in the United States, and has since its inception in 1960 granted over 200,000 degrees and certificates to students in a wide range of instructional programs. These programs are designed to prepare students for transfer to upper division colleges and universities, or to train or retrain them for highdemand occupations (MDC Institutional Research, 2004).

Demographically, the student population at Miami Dade College North Campus is $22.2 \%$ African-American, $65.3 \%$ Hispanic, 10.1\% Caucasian non-Hispanic, and 2.3\% Other. Further, the student body at the College is $61.7 \%$ female and $38.3 \%$ male, with a mean age of 28.25 years old. Specifically concerning those enrolled in Associate of Arts 
and Associate in Science programs, 67\% attend part-time (MDC Institutional Research, 2004). The subjects for this study were selected from the entire population of students in programs leading to the Associate in Arts and Associate in Science degrees at the North Campus who were registering for MAT 0020 and MAT 0024 (remedial mathematics courses) during the fall 2005 term.

\section{Instrumentation}

Two instruments were used to collect data for this study. The measure of basic ability in mathematics chosen for this study was the scores attained by students on the Computerized Placement Test (CPT), given to all newly-admitted individuals who declare the intention to pursue an associate degree at MDC. Completion of this test is required for degree seeking students at the college before any academic advisement is given or registration into courses is allowed. In addition to the CPT exam, the Study Behavior Inventory developed by Bliss and Mueller (1986) was given to all students participating in this study. This 46 -item inventory was used to determine the study behaviors and habits of the participants.

The Florida College Entry-Level Placement Test

The Florida College Entry-Level Placement Test (FCELPT), better known as the Computerized Placement Test (CPT), is an untimed examination that the majority of examinees complete in about 2 hours. A.A. or A.S. degree program students cannot register for courses at MDC until their CPT results are on file. If the students' scores are below the State mandated minimum scores, they are required to enroll in college preparatory classes. First-time-in-college students who have SAT or ACT scores that meet minimum state requirements are exempted from this testing. 
A review of the CPT was made by Schattgen (1994) in the $11^{\text {th }}$ Mental

Measurements Yearbook. That review of the reliability and validity of the CPT revealed a high degree of score accuracy for the test as well as high reliability coefficients ranging from .86 to .92 . The correlation coefficients from test-retest reliability ranged from .76 to .96 , and the reliability of classification estimated for selected CPTs ranged from .91 to 96. The review also explained that considerable effort had been made to minimize item bias, including cultural and linguistic bias. In addition, content and predictive validity were analyzed and were deemed adequate. In conclusion, the overall reliability and validity of the CPT were reviewed as "quite good" (Schattgen, 1994). The CPT was rated as an excellent system for evaluation and placement of students in appropriate courses.

A note of caution is appropriate here. The CPT norms reported above were based on a sample of examinees with a wider range of cognitive abilities than the sample of participants in this study. The former were a representative sample of the population of entering undergraduate students while the participants in this study were all taking remedial mathematics courses. The scores of a group of students taking remedial courses can be expected to be lower and more homogeneous than a more diverse sample of students and this should be considered when evaluating the reliability of the scores obtained by the sample of participants in this study on the CPT.

The Study Behavior Inventory

The second instrument that was given to students was the Study Behavior Inventory (SBI). The SBI was developed by Bliss and Mueller (1986). This instrument has a total of 46 items. These 46 inventory items have both positive and negative 
statements to avoid response set. Response choices are arranged on a 4-point Likert-type scale: (1) rarely or never true in my case, (2) sometimes true in my case, (3) often or usually true in my case, (4) always or almost always true in my case. The inventory takes approximately 15 to 20 minutes to complete.

Bliss and Mueller (1986) analyzed a student sample of 1052 undergraduates from three community colleges, a 4-year college, a state university, and a 4-year college in a U.S. Caribbean Territory. The instrument was administered during regular class sessions and the responses were anonymous. Factor analysis was used to determine the construct validity of the instrument. Three factors were obtained. The first factor was related to academic self-esteem, the second involved the preparation for routine academic tasks, and the third factor consisted of long-term preparation for academic activities (eg., special assignments and test taking).

The Study Behavior Inventory and the items in each of the three factors have internal consistency reliability ranging from .70 to .88 . These measures show high levels of internal consistency reliability for the complete instrument and the three factors. The reliability coefficient for the SBI was found to be .94 after using the test-retest method with a time interval of 3 weeks. This test-retest study tested 62 undergraduate students (Bliss \& Mueller, 1993). Based on these results, the Study Behavior Inventory is a valid and reliable instrument for assessing study behaviors of college and university students (Best \& Kahn, 1989).

\section{Procedures}

Since this study focused on student behavior and skills as they relate to the problem of retention and progress of non-traditional students who are underprepared for 
college-level academic studies, students who tested out of college preparatory math were not included as part of the student population for this study. The student population for this study was those who have scored at levels requiring that they take courses in developmental mathematics before attempting regular college level mathematics courses. As indicated above, the study was conducted during the fall 2005 term. A total of four classes in developmental mathematics (two MAT 0020 and two MAT 0024), each with an enrollment of 35 students were selected for the study. Two classes (one MAT 0020 and one MAT 0024) were randomly assigned as the treatment group and the other two classes as the control group. The instructors for the college survival and math classes each taught one treatment group and one control group. They were naïve concerning the purpose and expectation of the study and of the details of the Study Behaviors Inventory. The instructors were not informed of their students' pre-treatment scores on the SBI. After grades had been submitted they were debriefed concerning the purpose of the study and the reasons that different course materials were picked for the different classes.

In addition, every student in both groups was registered for a College Survival (SLS 1535) class where the SBI was administered during the first week of class to measure students' study behaviors. The SLS curriculum and time spent in the classroom were the same for the experimental and control groups. The instructors in the College Survival classes (SLS 1535) used a variety of teaching methods to instruct students. Lecture is the most commonly used method in community colleges because lectures are flexible and can be applied to any content and because typically planning time is limited (Shuell, 1996). But, to make lectures more interesting and useful to students a variety of 
other techniques were used. For example, modeling, simulation, and discussions are also used within the lecture format.

The instructors in all sections of the College Survival course used two books. The first book was Keys to Excellence (Cooper, 2004) and the second book was Cornerstone (Sherfield, Montgomery, \& Moody, 2000), but different chapters of the books were used with treatment group and control group students. Topics such as MDC students' rights and responsibilities, policies and procedures, establishing an MDC account, registration by phone and on-line, state and federal financial aid, availability of institutional funds, and use of FACTS.org was covered for both groups, but the rest of the content varied between the treatment and control groups. Instruction in the Control Group

With students in the control group instructors emphasized institutional involvement (e.g., career planning, campus resources, diversity in education, wellness, relationships, clubs, and activities). None of this content dealt with study behaviors or the self-regulatory attitudes that are associated with the use of appropriate study behaviors. The specific topics taught to students in the control group are listed in the appendix.

\section{Instruction in the Treatment Group}

Instructors working with students in the experimental group emphasized study behaviors associated with the three factors identified in the SBI. The teachers working with these students directed them in studying content that dealt with such ideas as motivation, success, time management, listening and note taking and note taking. This content includes the skills that, when actualized, constitute study behaviors and attitudes and feelings that moderate self-esteem. In fact, it is motivation that produces the self- 
regulatory attitudes that both increase self-esteem and actualize study skills to produce study behaviors (Aulls, Hou, Deckie, \& Hong, 2007). The specific topics taught to participants in the treatment group are listed in the appendix.

Two weeks before the semester was over, the SBI was administered again to both the treatment and control groups. Instructors assigned students' grades at the end of the semester. All grades were collected after the completion of the course.

\section{Data Analysis}

This research was conducted by running a quasi-experimental nonequivalent control group design (Jackard \& Becker, 1997). A series of analysis of covariance procedures were used to test the four hypotheses.

\section{Hypothesis 1}

In order to test Hypothesis 1 , an analysis of covariance was carried out using participants' end of semester score on the academic self-esteem factor of the Study Behavior Inventory as the dependent variable and their treatment group membership as the independent variable. The covariate was participants' beginning of semester scores on the academic self-esteem factor.

\section{Hypothesis 2}

In order to test Hypothesis 2, an analysis of covariance was carried out using participants' end of semester score on the routine academic tasks factor of the Study Behavior Inventory as the dependent variable and their treatment group membership as the independent variable. The covariate was the participants' beginning of semester scores on the routine academic tasks factor. 
Hypothesis 3

In order to test Hypothesis 3, an analysis of covariance was carried out using participants' end of semester score on the preparation for unique, long range academic tasks factor of the Study Behavior Inventory as the dependent variable and their treatment group membership as the independent variable. The covariate was the participants' beginning of semester scores on the unique, long range academic tasks factor. Hypothesis 4

In order to test Hypothesis 4, an analysis of covariance was carried out using participants' final course grades as the dependent variable and their treatment group membership as the independent variable. The covariate was the participants' scores on the Computerized Placement Test. 


\section{CHAPTER IV}

\section{RESULTS}

This chapter presents the results of the present study. This study investigated the effect of formal, purposeful, instruction in the use of appropriate study behaviors among college preparatory math students on their mathematics achievement. It specifically attempted to determine if there is evidence to suggest that there is a cause and effect relationship between the use of appropriate study behaviors and the level of achievement of community college students in remedial mathematics courses. This chapter also describes the sample and the tests of hypotheses used in the study.

\section{Description of the Sample}

At the beginning of the term the sample for this study was 142 entering students whose placement test scores on the Florida College Entry-Level Placement Test (FCELPT) placed them in a developmental mathematics course. Students so placed are also required to register in a College Survival class. There were 72 students in the experimental group and 70 in the control group. At the end of the semester, there were 63 students in the experimental group and 63 in the control group. In other words, a total of 126 students (89\%) stayed in the study and 16 students (11\%) dropped their classes. As shown by the percentage of students completing the study, the mortality rate for this study was low. More importantly, the fact that about the same number dropped from each group indicates that it was not the class or the treatment that affected the dropout rate. Table 1 presents descriptive statistics for the four classes used in the study. 
Table 1

Descriptive Statistics for SBI Factor Scores by Class

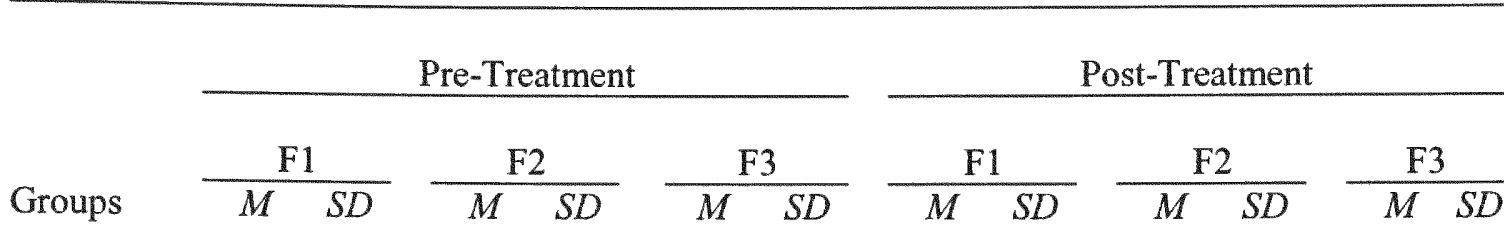

Treatment

$\begin{array}{lllllllllllll}\text { Class } 1 & 41.6 & 6.2 & 45.6 & 7.1 & 23.9 & 3.9 & 47.0 & 6.3 & 51.7 & 6.6 & 27.1 & 4.1\end{array}$

$\begin{array}{lllllllllllll}\text { Class } 3 & 38.0 & 9.7 & 39.8 & 5.5 & 21.6 & 3.6 & 44.8 & 9.1 & 50.1 & 7.7 & 26.1 & 4.1\end{array}$

Control

$\begin{array}{lllllllllllll}\text { Class } 2 & 39.7 & 6.8 & 43.8 & 6.5 & 23.0 & 3.8 & 38.5 & 6.3 & 42.7 & 6.9 & 22.0 & 3.3\end{array}$

$\begin{array}{lllllllllllll}\text { Class } 4 & 40.0 & 6.9 & 42.9 & 6.6 & 22.8 & 3.5 & 42.3 & 8.0 & 46.8 & 7.8 & 24.4 & 4.3\end{array}$

Note. F1-Self-esteem SBI factor

F2 - Time management in preparing for routine academic tasks SBI factor

F3 - Time management in preparing for long-range academic tasks SBI factor

Note that in the post-treatment scores each of the control classes performed more poorly than each of the experimental treatment classes on each of the three Study Behavior Inventory factors. From this finding it can be concluded that there were no teacher/class effects that might confound the inferences made from this data.

Tests of Hypotheses

Four hypotheses were tested at the .05 level by running a series of analysis of covariance procedures. The first three hypotheses proposed that students who were instructed in the use of appropriate study behaviors would score higher on the three factors of the Study Behavior Inventory after adjusting for their pre-test SBI scores. The 
fourth hypothesis proposed that a higher proportion of mathematics students who were instructed in the use of appropriate study behaviors than students who were in the control group would receive a passing grade in the their course.

\section{Hypothesis 1}

In order to test the first hypothesis an analysis of covariance was employed by using the post-treatment scores on the academic self-esteem factor of the Study Behavior Inventory as the dependent variable, treatment group membership as the independent variable, and pre-treatment scores on the academic self-esteem factor of the SBI as the covariate. The homogeneity of slopes was tested and the null hypothesis that the slopes were equal was not rejected, $F(1,122)=.79, p=.38$. Therefore, the homogeneity of slopes assumption was considered to have been met. Table 2 displays the source results of the ANCOVA testing of the null hypothesis that the adjusted mean scores of the treatment and control groups on the academic self-esteem factor of the SBI were equal. It was found that there was a significant difference between the adjusted mean post-treatment scores of the treatment group (adj. $M=45.86$ ) and the control group (adj. $M=38.71$ ) on the self-esteem factor of the Study Behavior Inventory. The conclusion is that the instruction on study skills had a favorable influence on the self-esteem scores of students measured after the course was completed. Further, the influence was substantial as indicated by the value of the $\eta^{2}$ statistic. Eta is the ratio of the between groups sum of squares to the total sum of squares. When squared it measures the variability in the dependent variable accounted for by the grouping factor. In this case it would found that $32 \%$ (almost one-third) of the variance of the score on the SBI Self-Esteem factor was due to the treatment. 
Table 2

ANCOVA for the SBI Self-Esteem Factor

Source

$d f$

F

$\eta^{2}$

$p$

Pre-treatment Self Esteem SBI Factor

$1 \quad 111.31^{*}$

.48

$<.001$

Treatment

1

$58.01^{*}$

.32

$<.001$

error

123

$(27.77)$

Note. Values enclosed in parentheses represent mean square errors

$*_{p}<.01$

Hypothesis 2

An analysis of covariance was used to test the second hypothesis. The dependent variable was the post-treatment scores on the time management for the preparation for routine, everyday tasks factor of the Study Behavior Inventory. The independent variable was the treatment group membership, and the covariate was the pre-treatment scores on the time management for the preparation for routine, everyday tasks factor of the SBI. The assumption of homogeneity of slopes was rejected: $F(1,122)=5.53, p=.02$.

However, it has been found that when the sample sizes are equal or close to equal, the ANCOVA is robust with respect to violation of assumptions of homogeneity variance (Hinkle, Wiersma, \& Jurs, 2003). Therefore, the analysis of covariance was carried out. Table 3 displays the source table for this analysis.

Table 3 
ANCOVA for the SBI Time Management for the Preparation for Routine, Everyday Tasks

Factor

Source

$d f$

F

$\eta^{2}$

$p$

Pre-treatment Routine Tasks Factor

$138.93^{*}$

$.24<.001$

Treatment

1

$67.47^{*}$

.35

$<.001$

error

123

$(35.51)$

Note. Values enclosed in parentheses represent mean square errors

$* p<.01$

There was a significant difference between the adjusted mean post-treatment scores of the treatment group (adj. $M=51.03)$ and the control group (adj. $M=42.55$ ) on the time management for the preparation for routine, everyday tasks factor of the Study Behavior Inventory. It was concluded that instruction on study skills had a favorable influence on the frequency of participants' use of appropriate study behaviors for preparing for routine, every-day academic tasks measured after the course was completed. The $\eta^{2}$ value of .35 indicates that over a third of the variance in the SBI Time Management for the Preparation for Routine, Everyday Tasks factor could be accounted for by treatment. This is a strong effect size. 
Hypothesis 3

The third hypothesis was also tested using an analysis of covariance. The dependent variable was the post-treatment scores on the preparation for unique, long range academic tasks factor of the Study Behavior Inventory. The independent variable was the treatment group membership, and the covariate was the pre-treatment scores on the unique, long range academic tasks factor of the SBI. The homogeneity of slopes assumption was met, $F(1,122)=2.17, p=.14$. Table 4 displays the source table for the test of the null hypothesis that the scores of the treatment and control groups on the unique, long range academic tasks factor of the SBI were significantly different.

Table 4

ANCOVA for the SBI Time Management for the Preparation for Long Range, Unique Academic Tasks Factor

Source

$d f$

F

$\eta^{2}$ $p$

Pre-treatment Long Range Tasks Factor

$1 \quad 17.61^{*}$ .13 $<.001$

Treatment

$50.91^{*}$

.29

$<.001$

error

123

(12.25)

Note. Values enclosed in parentheses represent mean square errors

${ }^{*} p<.01$

There was a significant difference between the adjusted mean post-treatment scores of the treatment group (adj. $M=26.61)$ and the control group (adj. $M=22.16$ ) on the unique, 
long range academic tasks factor of the Study Behavior Inventory. It was concluded that instruction on study skills had a favorable influence on the frequency of participants' use of appropriate study behaviors for preparing for unique, long range academic tasks measured after the course was completed. The effect size was, as in the case of the other two SBI factors, was substantial $\left(\eta^{2}=.29\right)$ indicating that the treatment had a considerable effect on the variability of the Preparation for Long Range, Unique Academic Tasks Factor score of the SBI.

Hypothesis 4

The mean College Placement Test mathematics scores for the two treatment groups were equal with the both groups scoring a mean of 58.19. The control group scores were more homogeneous having a standard deviation of 15.70 compared with a standard deviation of 16.26 for the scores of the group receiving instruction in the use of appropriate study behaviors. From this it was concluded that there was no need to consider pre-treatment differences in mathematics achievement in comparing the proportion of participants in the two groups who received passing grades in the developmental mathematics courses. It was found that $60.3 \%$ of the participants in the group receiving instruction in using appropriate study behaviors received a passing grade in the course compared to $38.1 \%$ in the control group. This difference in proportions was significant $(p=.02)$, confirming the hypothesis.

\section{Summary}

This study revealed significant differences in both the use of appropriate study behaviors and mathematics achievement between participants who received instruction in appropriate study behaviors and math students who did not. The group of students 
receiving instruction in study behaviors demonstrated superior use of appropriate study behaviors on all three factors of the Study Behavior Inventory and its members were more likely to pass the developmental mathematics course. The following chapter suggests explanations for these findings and strategies for using these findings in higher education instruction. 


\section{CHAPTER V \\ DISCUSSION}

This chapter presents a summary of this study, a discussion of its findings, and recommendations based on those findings. The purpose of this study was twofold. First, it was designed to determine the efficacy of an intervention designed to increase the frequencies of appropriate study behaviors on the part of community college students who were preparing for academic mathematics activities. Next, it was designed to determine whether this increase in appropriate study behavior frequency was accompanied by increased academic achievement in developmental (college preparatory) mathematics courses as measured by course grade.

A non-equivalent group, pretest-posttest design was conducted to test two research questions. The three hypotheses of the first question stated that preparatory math students who were instructed in the use of appropriate study behaviors will score higher on the academic self-esteem factor; preparation for everyday, routine academic tasks factor; and on the preparation for unique, long range academic tasks factor of the Study Behavior Inventory than those students who were not so instructed. The hypothesis for the second research question stated that preparatory math students who were instructed in the use of appropriate study behaviors will have higher final course grades than those who were not so instructed.

The subjects for the study were 126 first-time in college students enrolled in a college preparatory math class and a College Survival class during the 2006 fall term. These students were enrolled in four sections of a developmental mathematics class. Two of these classes were randomly assigned to the experimental treatment and the other two 
classes served as the control group. Students in all four classes were administered the Study Behavior Inventory during their College Survival class at the beginning of the semester and again at the end of the semester. Two instructors each taught one of the classes receiving the experimental treatment and one control class. Likewise, a different pair of instructors each taught the College Survival to one of the classes receiving the experimental treatment and to one of the control groups. The data were used to test the four hypotheses using analysis of covariance and Fisher's Exact Test.

The results of the data analysis showed higher mean adjusted post-treatment scores on all three factors of the Study Behavior Inventory for students in the classes that received experimental treatment than for students who were in classes that received the control treatment. In addition, a larger percentage of students who received the experimental treatment received passing grades in the mathematics course than the percentage of students passing in the control group.

\section{Discussion of the Findings}

The findings of this study are consistent with correlational studies that found a strong relationship between the use of effective study behaviors and student success (e.g., Hunter, 1979). In addition, based on this study, there is evidence to suggest that there is a cause and effect relationship between appropriate study behaviors and the level of achievement of community college students in remedial mathematics courses. A related finding of the present study, that the use of appropriate study behaviors can be taught to college preparatory students supports recent investigations done by Gettinger and Seibert (2002), Horner and Shwery (2002), and by Elliot, Foster, and Stinson (2002) that have 
revealed that appropriate study behaviors and other self-regulatory behaviors can be taught both to high school and post-secondary students.

Bandura (1989) has provided a theoretical framework for understanding interactions between student beliefs, behaviors, and environment that ground these empirical study findings. Bandura's Social Cognitive Theory also identifies methods to transform or modify student behaviors. According to Social Cognitive Theory, instructors should both rectify students' inadequate self-belief and way of thinking to enhance their positive emotional states (personal factors) and improve the students' academic skills and self regulatory practices (behavior), in order to transform the classroom structures by modification of behavior (environmental factor). The dynamic interplay of these three factors is made possible through the students' cognition, which encourages self-reflection and self-regulation of their behavior.

In this study the College Survival class focused on enhancing students' selfefficacy through their modeling appropriate behavior under the direction of their instructors. The experimental group was also taught more appropriate study behaviors based on their Study Behavior Inventory identified weaknesses and strengths. This information provided students with the knowledge they needed in order to self-reflect, self-regulate their learning skills and behaviors, and work in conjunction with the math class and the math lab to practice those learned behaviors. Specifically they learned to reduce math fear and anxiety, enhance self-esteem, and improve test taking skills and time management. It is worth noting here, too, that this group of students also demonstrated higher academic achievements in their math class than the control group. As predicted by Social Cognitive Theory, it appears that for these students, improving 
their self-efficacy and their use of appropriate self-regulation strategies improved their learning behavior.

\section{Self-Efficacy and Self-Esteem/Academic Self-Esteem}

Self-efficacy and self-esteem were heavily emphasized by the instructors and the lab tutors since research has demonstrated that when self-efficacy is low, the students give up relatively easily by avoiding tasks or putting them off (Bandura, 1997). College preparatory students who have a weakness in math tend to be reluctant to engage in mathematics classes, and students who believe that they do not have mathematical abilities are afraid of math and show a low level of self-efficacy and competence in math (Deck 1990). The students in this study had deficiencies in math, and like the majority of college preparatory students, may well have been so intimidated.

In this study, the lab tutors worked in conjunction with the math instructors. Also the focus of the College Survival (SLS 1535) experimental classes was on learning strategies necessary to overcome math self-efficacy fears and low self-esteem. This was done because as has been pointed out by researchers (e.g., Bandura, 1997; Zimmerman, 1989), when students have low self-efficacy, they also have low self-esteem. Their resultant lack of self-regulatory learning behavioral strategies creates a lack of selfmotivation to perform any type of tasks (everyday or long range tasks). The students in the experimental group spent considerable time discussing and internalizing strategies to improve their motivation and self-esteem in order to overcome their doubts and fears. They also learned to both identify behaviors associated with poor self-esteem and how to remedy those behaviors. 
Time Management and Goal Setting - Routine, Everyday Tasks

Not unexpectedly, Bliss and Mueller (1993) found that the management of time while preparing for academic tasks was a set of study behaviors that correlated highly with academic achievement. Social Cognitive Theory researchers agree that effective individuals are in control of their thoughts, their behaviors, and their environment (Gredler \& Schwartz, 1997; Miller, Behrens, Greene, \& Newman, 1993). Since the college that was the site of this study has a non-traditional population, sometimes it is very challenging for the students to manage school, work, and their personal lives. For that reason, the topic of time management was an important focus of discussion and reflection among the experimental group students in this study. Great emphasis was placed on establishing goals for the SLS and Math classes, strengthening note taking and listening skills, planning-time to attend classes and the lab, and also teaching learning styles and study strategies to take control of their school responsibilities and personal lives.

Self-regulation and Metacognition - Long Range Unique Tasks

As Pressley and Wharton-McDonald (1997) pointed out, students tend to improve academically when they self-regulate their learning strategies and their study behaviors. The students in the treatment group were taught to be self-regulated students. For instance when the experimental group students had to do a semester long group project, they had to:

- At the beginning of the semester, set the goals for the project and plan the distribution of assignments among the group members.

- Delineate an action plan to prepare and organize the research topic for the project. 
- Throughout the semester, monitor the progress of the research by arranging meeting times to discuss the assignments and to understand the researched material that was going to be presented in class.

- Practice self regulation during the meetings by schedule breaks when their concentration was diminishing.

- Change the learning environment when it was distracting to the progress of the group project.

This being said, following Tinto's Integration Theory, perhaps the most important aspect of the experimental groups' College Survival class was that these students were taught to have good communication with the instructors and to ask them for assistance when needed. By working with other students in a group and by developing close contact with instructors, these students had the opportunity to develop strong social and academic integration. This integration enhanced their chances for academic success and, in turn, their retention.

Through these aspects of the treatment, the experimental group students in this study were taught to be active learners and to use critical thinking skills in college and in their personal lives. The Social and Academic Integration of Tinto's theory may be related to elements of Bandura's Social Cognitive Theory. One important aspect of Bandura's Social Cognitive Theory is that a student's behavior, personal life, and the environment are in constant interaction. For Bandura, interactions among these three elements modify students' learning behavior. Finding of this study support Zimmerman's (1989) research showing that self-regulatory activities influence students' cognition by creating learners who are aware of their strengths and weaknesses. By 
teaching and having them practice self-regulatory strategies, these students became more aware of their learning behaviors, learning styles, and personality types and thus learn to be self-regulated students. As many studies, including this one, have demonstrated, students who can self-regulate their study behaviors find a way to learn the material that is presented to them, apply strategies for test-taking skills, and control and understand the importance of their study environment.

Further, the findings of this study support the findings of studies by Perkins, (1995) and by Pintrich and DeGroot (1990) that have shown that students can be taught to enhance their academic performance using meta-cognitive strategies such as these. Metacognition activities influence cognition by making students aware of their strengths and weaknesses providing opportunities and incentives to work towards remedying their weaknesses. According to Perkins (1995), the more information students have in reference to effective learning strategies, the greater their meta-cognitive awareness will be. Similarly, Zimmerman (1995) showed that the more aware a student with poor academic performance is about how he/she learns and how to control the learning process, the better equipped this student will be academically.

Finally, studies done by Nokes and Ohlsson (2001) and by Tobias (1993) have focused on the inculcation and repetition of behaviors that have been shown to assist in learning abstract subject matter, such as math. These research studies indicate that instruction in the process of solving mathematics problems, together with actual practice and repetition of solving these problems, is the most effective method of resolving math avoidance and math anxiety difficulties. The treatment students in the present study were 
made more aware of their study behavior needs and practiced those needed behaviors more often in class and in the lab.

Conclusions and Recommendations for Practice and Future Research Higher education institutions across the nation need to implement different strategies to resolve the tremendous problems associated with low levels of student retention. A lack of student success during students' first year in college is adversely affecting graduation rates in institutions of higher education, resulting in problems for the students and considerable reductions in funding for the institutions. The site of this study, Miami Dade College (MDC), shares statewide problems related to low student college and university retention rates (Sun-Sentinel, 2007). In addition, MDC is one of those institutions that maintains its commitment to open access and consequently has a high percentage of non-traditional students attending its campuses. Based on institutional research figures compiled by MDC, mathematics is the subject area in which students have the greatest difficulty, a difficulty that causes them to leave the institution without completing a degree (MDC Institutional Research, 2006).

Tinto's Theory of Attrition (1993) suggests that students who do poorly academically are more likely to drop out of college than those students who do well. For that reason this study was designed with the purpose of investigating whether there was a cause and effect relationship between the use of appropriate study behaviors and academic achievement among community college students, and also whether the use of appropriate study behaviors can be taught to students. In other words, this study was undertaken in recognition of a serious problem of student retention that is affecting 
higher education institutions, and to explore one strategy being taken to ameliorate this problem; teaching study behaviors to academically under prepared mathematics students. This study demonstrated that study behaviors can be taught to college preparatory students, and that they can improve academically by practicing those learned behaviors. This suggests that colleges with open access policies should incorporate administration of the Study Behavior Inventory or some other measure of study behaviors as part of its new student intake process. This procedure would allow students to become more aware of their strengths and weaknesses in the first semester. Colleges should develop classes, such as MDC's College Survival class to help developmental students remediate their deficiencies by facilitating their learning and using appropriate study behaviors. Not only it is beneficial for these students to know and understand the frequency of their use of appropriate study behaviors, it is also important that instructors know the areas of weaknesses and strengths of their developmental students so that they can teach them more effectively. Since the College Survival class is meant to accommodate new developmental students to the college environment, this would appear to be an appropriate place in the curriculum for these activities.

If a college cannot afford to screen all entering students, an alternative to that might be the administration of some measure of study behaviors only to students placed in a developmental class such as the College Survival class due to their academic deficiencies. At MDC, this class is required for every new student who scores below a state mandated cut off point on the computerized placement test (CPT), making it a good class to teach study behavior to college preparatory/developmental students. They are a population in great danger of dropping out of college. The faculty and math lab 
managers and tutors should work together to understand the measurement instrument used and to be able to use results from it to teach appropriate study behaviors. Relatedly, there should be a strong collaboration and an effective working relation among faculty, lab managers, and lab tutors to assist students and inculcate them with the repetition of study behaviors and skills.

This study showed that preparatory students who were taught to use appropriate study behavior did increase their sense of self-efficacy and their practice of self-regulated good study behaviors - and did perform significantly better academically in their math class. Based on these findings other researchers should investigate whether these students continue to benefit throughout their college years. Do they retain those learned study behaviors? Do their GPAs continue being higher than the control group?

Likewise, more research is needed to find out if the procedure followed in this study also increases the practice of good study behaviors and academic success in other subjects. Students who place into developmental courses often attend English and or reading remedial classes as well as math ones. Success in all these classes is a prerequisite to continue their college level academic classes. Knowing more about successful practices with preparatory students will help college administrators make better curricula and funding decisions for them.

Finally, because student attrition is a problem even at colleges without open access, it is important to conduct more research about instruction that might increase the retention of "regular" non-preparatory students. Can the present study be replicated with regular students? Researchers might also conduct a study similar to the present one, but in other academic subjects that regular students have difficulty with, such as science. 
It is imperative to continue conducting research in this area. A more complete picture of how colleges can help students identify and improve their learning behaviors will not only help those students achieve better integration with and academic success at their institutions, but will also help those who facilitate the management of resources at those institutions. Ultimately, if these students are successful, the institution will be more successful and society will benefit. College graduates can get better jobs and thus raise the standard of living in the entire community. 


\section{REFERENCES}

Ames, C. (1992). Classrooms: Goals, structures, and student motivation. Journal of Education Psychology, 84, 261-271.

Ames, C., \& Archer, J. (1998). Achievement goals in the classroom: Students' learning strategies and motivation processes. Journal of Educational Psychology, 80, 260267.

Astin, A.W. (1975). Preventing students from dropping out. San Francisco: Jossey-Bass.

Astin, A. W. (1977). Four critical years: Effects of college on beliefs, attitudes, and knowledge. San Francisco: Jossey-Bass.

Astin, A.W. (1985). Achieving educational excellence. San Francisco: Jossey-Bass.

Astin, A.W. (1993). What matters in college? Four critical years revisited. San Francisco: Jossey-Bass.

Auls, M. W., Hou, D., Deckie, L., \& Hong, Y. (2007, April). The relationship between contexts, effective teaching strategies, obstacles and approaches to instruction in colleges. Paper presented at the annual meeting of the American Educational Research Association, Chicago, IL.

Bandura, A. (1977). Social learning theory. Englewood Cliffs, N.J: Prentice-Hall.

Bandura, A. (1986). Social foundations of thought and action: A social cognitive theory. Englewood Cliffs, NJ: Prentice-Hall.

Bandura, A. (1989). Social cognitive theory. Annals of Child Development, 6, 1-60.

Bandura, A. (1997). Self-efficacy: The exercise of control. Englewood Cliffs, NJ: Prentice-Hall.

Bean, J., \& Metzner, B. (1985). A conceptual model of nontraditional undergraduate student attrition. Review of Educational Research, 55, 485-540.

Bean, J., \& Metzner, B. (1987). The estimation of a conceptual model of nontraditional undergraduate student attrition. Research in Higher Education, 27(1), 15-38.

Bender, D. S. (1997, February). Effects of study skills programs on the academic behaviors of college students. Paper presented at the annual meeting of the Eastern Educational Research Association, Hilton Head, SC. (ERIC Document Reproduction Service No. ED40897) 
Best, J. W., \& Kahn, J.V. (1989). Research in education $\left(6^{\text {th }}\right.$ ed.). Upper Saddle River, NJ: Prentice Hall.

Bliss, L. B., \& Mueller, R. J. (1986, April). An instrument for the assessment of study behaviors of college students. Paper presented at the annual meeting of the American Educational Research Association, San Francisco, CA (ERIC Document Reproduction Service No. ED268180)

Bliss, L. B., \& Mueller, R J. (1987). Assessing study behaviors of college students: Findings from a new instrument. Journal of Developmental Education, 11(2), 1418.

Bliss, L. B., \& Mueller, R. J. (1993). An instrument for the assessment of study behaviors of college students. Reading Research and Instruction, 32(4), 46-52.

Bliss, L. B., \& Sandiford, J. R. (2002). The effects of institutional culture on study strategies of Hispanic students as measured by the "Inventario de Comportamiento de Estudio": The Spanish version of the Study Behavior Inventory. Paper presented at the annual meeting of the American Educational Research Association, New Orleans, LA. (ERIC Document Reproduction Service No. ED464941)

Bliss, L. B., Vinay, D. M. A., \& Koeninger, F. (1996, April). First steps in the development of the "Inventario de Comportamiento de Estudio": The Spanish version of the "Study Behavior Inventory". Paper presented at the annual meeting of the American Educational Research Association, New York, NY. (ERIC Document Reproduction Service No. ED 399 279)

Boughan, K. (1995). Developmental placement and academic progress: Tracking "atrisk" students in the 1990 entering cohort. (ERIC Document Reproduction Service No. ED377908)

Boylan, H. R. (1999). Exploring alternatives to remediation. Journal of Developmental Education, 22(3), 2-8.

Brawer, F. B. (1995). Retention-attrition in the nineties. (ERIC Clearinghouse for Community Colleges DIG 9606)

Brittenham, R., Cook, R., Hall, J.B., Moore-Whitesell, P., Kuhl-Smith, C., ShafiiMousavi et al., (2003). Connections: An integrated community of learners. Journal of Developmental Education, 27(1), 18-25.

Brown, A.L. (1987). Metacognition, executive control, self-regulation, and other more mysterious mechanisms. In F.E. Weinert \& R.H. Kluwe (Eds.), Metacognition, motivation, and understanding (pp. 65-116). Hillsdale, NJ: Lawrence Erlbaum. 
Brown, J. (1986). The effects of the City University of New York freshman skills assessment program: One college's experience. (ERIC Document Reproduction Service No. ED281868)

Brown, W. F. (1972). Student-to-student counseling. Austin: University of Texas Press.

Brown, W. F., \& Holtzman, W. H. (1966). Survey of study habits and attitudes. New York: Psychological Corporation.

Cabrera, A. F., Castaneda, M. R., \& Nora, A. (1993). College persistence: Structural equations modeling test of an integrated model of student retention. Journal of Higher Education, 65(2), 123-139.

Cabrera, A.F., Castaneda, M.R., Nora, A., \& Hengstler, D. (1992). The convergence between two models of college student persistence. Journal of Higher Education, 63(2), 146-164.

Cone, A.L., \& Owens, A.K. (1991). Academic and locus of control enhancement in a freshman study skills and college adjustment course. Psychological Reports, 68, 1211-1217.

Cooper, C. (2004). Keys to excellence. Dubuque, IA: Kendall/Hunt.

Demitroff, J. F. (1974). Student persistence. College and University, 49, 553-567.

Dweck, C. S., \& Leggett, E. L. (1988). A social-cognitive approach to motivation and personality. Psychological Review, 95(2), 256-273.

Elliot, L., Foster, S., \& Stinson, M. (2002). Student study habits using notes from a speech-to-text support service. Exceptional Children, 69(1), 25-40.

Elliott, T. R., Godshall, F., Shrout, J. R., \& Witty, T. E. (1990). Problem-solving appraisal, self-reported study habits, and performance of academically at-risk college students. Journal of Counseling Psychology, 37(2), 203-207.

Farabough-Dorkins, C. (1991). Why older students drop out of college. (ERIC Document Reproduction Service No. ED332598)

Faro-Schroeder, J. D. (1995). Development education: Factors that contribute to academic success in community colleges. (Doctoral dissertation, Southern Illinois University at Carbondale, 1995). Dissertation Abstracts International, 56, 00144.

Feldman, M. J. (1993). Factors associated with one-year retention in a community college. Research in Higher Education, 34(4), 503-512. 
Flavell, J.H. (1979). Metacognition and cognitive monitoring: A new area of cognitivedevelopmental inquiry. American Psychologist, 34, 906-911.

Florida Department of Education. (2001). Readiness for college. (Performance of 199899 Florida Public High School Graduates on Entry-Level College Placement Tests in the 1999-2000 Academic Year). State Summaries. Tallahassee, FL.

Florida Department of Education. (2003). Implementation of House Bill 23-B. (Memorandum No. 03-27). Tallahassee, FL.

Gersten, R. (1998). Recent advances in instructional research for students with learning disabilities: An overview. Learning Disabilities Research \& Practice, 13(3), 162 170.

Gettinger, M., \& Seibert, J. K. (2002). Contributions of study skills to academic competence. School Psychology Review, 31, 350-365.

Gillis, M. R., \& Olson, M. W. (1989). Effects of teaching learning strategies with course content. San Marcos, TX: Southwest Texas State University. (ERIC Document Reproduction Service No. ED339259)

Gredler, M.E., \& Schwartz, L. S. (1997). Factorial structure of the Self-efficacy for SelfRegulated Learning Scale. Psychological Reports, 81, 51-57.

Gorrell, J., \& Capron. E. (1990). Cognitive modeling and self-efficacy: Effects on preservice teachers' learning of teaching strategies. Journal of Teacher Education, 41(2), 15-22.

Greene, B.A., \& Miller, R. B. (1996). Influences on course achievement: Goals, perceived ability, and cognitive engagement. Contemporary Educational Psychology, 21, 191-192.

Haught, P. A. (1996, April). Impact of intervention on disadvantaged first year students who plan to major in health sciences. Paper presented at the annual meeting of the American Educational Research Association, New York, NY. (ERIC Document Reproduction Service No. ED394468)

Hinkle, D. E., Wiersma, W., \& Jurs, S. G. (2003). Applied statistics for the behavioral sciences $\left(5^{\text {th }}\right.$ ed.). Boston, MA: Houghton Mifflin.

Holderman, R. D. (1995). An examination of the effectiveness of developmental and remedial education programs in two public community colleges. (Doctoral dissertation, George Washington University, 1995). Dissertation Abstracts International, AAT 374152. 
Horner, S. L., \& Shwery, C. S. (2002) Becoming an engaged, self-regulated reader. Theory into Practice 41(2), 102-109.

House, J. D. (2000). Academic background and self-beliefs as predictors of student grade performance in science, engineering and mathematics. International Journal of Instructional Media 27, 207-220.

Hrabowski, F. A. (2003). Raising minority achievement in science and math. Educational Leadership, 60(4), 44-48.

Hunter, W. E. (1979). Non-cognitive factors and student success in college. Community College Frontiers, 7, 44-47.

Jackard, J., \& Becker, M. A. (1997). Statistics for the behavioral sciences $\left(3^{\text {rd }}\right.$ ed.). Pacific Grove, CA: Brooks/Cole.

Judd, T. P., et al. (1985, March). A research based approach to students in academic difficulty: Characteristics and intervention. Paper presented at the annual meeting of the Association for the Study of Higher Education, Chicago, IL. (ERIC Document Reproduction Service No. ED259631)

Kuhn, D. J. (1988). Experiences in community college science education: Restructuring the past and preparing for the future. College Student Journal, 22, 282-286.

Lin, Z. (2001). Metacognitive activities. Educational Technology Research and Development 49(2), 23-40.

Louisiana State University. (2006). LSU Center for academic success 2005-2006 Annual Report. Retrieved January 3, 2007, from www.cas.lsu.edu

MacGrath, M., \& Baunstein, A. (1997). The prediction of freshman attrition: An examination of the importance of certain demographic, academic, financial and social factors. College Student Journal, 31(3), 396-408.

MacKinnon-Slanery, F. (1994). The adult persistence in learning model: A roadmap to counseling services for adult learners. Journal of College Student Development, $72(3), 268-275$.

Martin, D. C., Lorton, M., Blanc, R. A., \& Evans, C. (1977). The learning center: A comprehensive model for colleges and universities. Grand Rapids, MI: Aquinas College. (ERIC Document Reproduction Service No. ED162294)

Miami Dade College. (2002). Institutional Research (2001-2002). Miami, FL.

Miami Dade College. (2003). Institutional Research (2002-2003). Miami, FL. 
Miami Dade College. (2004). Institutional Research (2003-2004). Miami, FL.

Miami Dade College. (2006). Institutional Research (2005-2006). Miami, FL.

Miller, R.B., Behrens, J. T., Greene, B.A., \& Newman, D. (1993). Goals and perceived ability: Impact on student valuing, self-regulation and persistence. Contemporary Educational Psychology, 18, 2-14.

Morris, C. (2003). Miami-Dade Community College graduate profile 1999-2000. Miami Dade Community College, Office of Institutional Research, Miami, FL.

Mueller, R. J. L., \& Gibson, E. E. (1982). Study behavior inventory. Unpublished manuscript, Northern Illinois University.

Mueller, R. J., \& Gibson, E. E. (1983). The study behavior of community college students. Dekalb, IL: Northern Illinois University. (ERIC Document Reproduction Service No. ED231422)

Multon, K. D., Brown, S. D., \& Lent, R. W. (1991). Relation of self-efficacy beliefs to academic outcomes: A meta analytic investigation. Journal of Counseling Psychology, 38(1), 30-38.

National Center for Education Statistics. (2002). Percent of degree-granting institutions offering remedial services, by type and control of institution: 1987-88 to 2000-01. Washington, DC: Author. Retrieved May 11, 2004, from http://www.nccs.ed.gov

Nolen, S. B. (1988). Reasons for studying: Motivational orientations and study strategies. Cognition and Instruction, 5, 269-287.

Nokes, T.J., \& Ohlsson, S. (2001). How is abstract generative knowledge acquired? A comparison of three learning scenarios. In J. D. Moore \& K. Stenning (Eds.), Proceedings of the twenty third annual conference of the Cognitive Science Society (pp.710-715). Mahaw, NJ: Erlbaum.

Ormrod, J.E. (2000). Education psychology ( $3^{\text {rd }}$ ed.). Columbus, OH: Merrill.

Pascarella, E. T. (1986, February). Long-term persistence of two-year college students. Paper presented at the annual meeting of the Association for the Study of Higher Education (ASHE), San Antonio, TX. (ERIC Document Reproduction Service No. ED268900)

Pascarella, E. T., \& Terenzini, P. T (1998). Studying college students in the $21^{\text {st }}$ century: Meeting new challenges. The Review of Higher Education, 21(2), 151-165. 
Paulos, J.A. (1988), Innumeracy: Mathematical illiteracy and its consequences. New York: Hill \& Wang.

Perkins, D.N. (1995). Outsmarting IQ: The emerging science of learnable intelligence. New York: Free Press.

Pierog, J. J. (1976). An investigation to determine if a positive correlation exists between student scores on the survey of study habits and attitudes and students' grade point average. (ERIC Document Reproduction Service No. ED124222)

Pintrich, P.R., \& DeGroot, E.V. (1990). Motivational and self-regulated learning components of classroom academic performance. Journal of Educational Psychology, 82, 33-40.

Poulsen, S.C. (1975). The study-methods in Mathematics Project I: Background, assumptions and perspectives. (ERIC Document Reproduction Service No. ED129628)

Pressley, M., \& Afflerbach, P. (1995). Verbal protocols of reading: The nature of constructively responsive reading. Hillsdale, NJ: Lawrence Erlbaum Associates.

Pressley, M., \& Wharton-McDonald, R. (1997). Skilled comprehension and its development through instruction. School Psychology Review, 26, 446-448.

Ramist, L. (1981). College student attrition and retention. Findings, 6, 1-4.

Rasor, L. T., \& Rasor, R. A. (1998). Test anxiety and study behavior of community college students in relation to ethnicity, gender, and age. (ERIC Document Reproduction Service No. ED415942)

Roueche, J., \& Roueche, S. (1993). Between a rock and a hard place: The at risk student in the open door college. Washington DC: Community College Press.

Sagher, Y., \& Siadat, M. V. (1997). Building study and work skills in a college mathematics classroom. Chicago City Colleges, Richard J. Daley College. (ERIC Document Reproduction Service No. ED449834)

Schattgen, S.F. (1994). The eleventh mental measurement yearbook: Book review. Journal of Educational Measurement, 31, 271-274.

Shuell, T. J. (1996). Current research on individual differences in learning and instruction. (ERIC Document Reproduction Service No. ED169123) 
Schmelzer, R. V., Schmelzer, C. D., Figler, R. A., \& Brozo, W. G. (1987). Using the critical incident technique to determine reasons for success and failure of university students. Journal of College Student Personnel, 28(3), 261-266.

Schunk, D. H. (1981). Modeling and attributional effects on children's achievement: A self-efficacy analysis. Journal of Educational Psychology, 73(1), 93-105.

Seon, Y., \& King, R. (1997). Study skills can make a major difference. (ERIC Document Reproduction Service No. ED417791)

Shayer, M., Kuchemann, D.E., \& Wylan, H. (1976). The distribution of Piagetian stages of thinking in British middle and secondary school children. British Journal of Educational Psychology, 48, 62-70.

Sherfield, R. M., Montgomery, R. J., \& Moody, P. (2005). Cornerstone: Building on your best. East Rutherford, NJ: Prentice Hall.

Silver, B. (1999). Indicators of academic achievement: A structural equation model. (Doctoral dissertation, University of Connecticut, 1999). Dissertation Abstracts International, 60, 9926293.

Simmons, A. B. (1996). Beliefs and academic performance of low-achieving college students (Doctoral dissertation, Indiana University, 1996). Digital Dissertations, AAT 9715334.

Solomon, L. J., \& Rothblum, E. D. (1984). Academic procrastination: Frequency and cognitive-behavioral correlates. Journal of Counseling Psychology 31, 503-509.

Spady, W. (1970). Dropouts from higher education: An interdisciplinary review and synthesis. Interchange, 1, 64-85.

Stallworth-Clark, R., Nolen, M. T., Warkentin, R., \& Scott, J. S. (2000, April). College students ' performance: The interaction of strategy engagement, content, and context. Paper presented at the annual meeting of the American Educational Research Association, New Orleans, LA. (ERIC Document Reproduction Service No. ED442443)

Stewart, K. J. (1984, April). Study strategy use and comprehension monitoring accuracy of college students. Paper presented at the annual meeting of the American Psychological Association, Toronto, Ontario, Canada. (ERIC Document Reproduction Service No. ED250640)

Sutherland, P. (1982) An expansion of Peel's describer-explainer stage theory. Educational Review, 34(1), 69-76. 
Thombs, D. L. (1995). Problem behavior and academic achievement among firstsemester college freshmen. Journal of College Student Development, 3(6), 280288.

Thompson, M. E. (1977). An appraisal of study methods inventories. (ERIC Document Reproduction Service No. ED138622)

Tinto, V. (1975). Dropout from higher education. A theoretical synthesis of recent research. Review of Educational Research, 45, 89-125.

Tinto, V. (1993). Leaving college: Rethinking the causes and cures of student attrition $\left(2^{\text {nd }}\right.$ ed.). Chicago: University of Chicago Press.

Tinto, V. (1998). Colleges as communities: Taking research on student persistence seriously. The Review of Higher Education, 21(2), 167-177.

Tobias, S. (1993). Overcoming math anxiety (Rev. ed.). New York: W.W. Norton \& Company.

Tollefson, N., et al. (1979, April). Study behavior and academic achievement. Paper presented at the annual meeting of the Association for the Study of Higher Education, Washington, DC. (ERIC Document Reproduction Service No. ED268180)

Travis, S. (2007, February 13). Forget a four-year degree: Florida, many students take 6 years or more to finish college. Sun-Sentinel. Retrieved February 13, 2007, from www.sun-sentinel.com

Tuckman, B. W. (1990, April). Measuring procrastination attitudinally and behaviorally. Paper presented at the annual meeting of the American Educational Research Association, Boston, MA. (ERIC Document Reproduction Service No. ED319792)

Tuckman, B. W. (2001, April). The Strategies for achievement approach (STACH) for teaching "Study Skills." Paper presented at the annual meeting of the American Educational Research Association, Seattle, WA. (ERIC Document Reproduction Service No. ED453240)

Vispoel, W.P., \& Chen, P. (1990, April). Measuring self-efficacy: The state of the art. Paper presented at the annual meeting of the American Educational Research Association, Boston, MA. (ERIC Document Reproduction Service No. ED338712) 
Warketin, R. W., Griffin, B., \& Bates, J. A. (1994, April). The relationship between college students' study activities, content knowledge structure, academic selfefficacy and classroom achievement. Paper presented at the annual meeting of the American Educational Research Association, New Orleans, LA. (ERIC Document Reproduction Service No. ED374152)

Weiner, B. A. (1979). Theory of motivation for some classroom experiences. Journal of Educational Psychology, 71, 3-25.

Weinstein, C. E., Schulte, A. C., \& Palmer, D. R. (1987). Learning and study strategies inventory (LASSI). Clearwater, FL: H \& H Publishing.

Welkowitz, L. A., \& Calkins, R. P. (1984). Effects of cognitive and exemplar modeling on field dependence-independence. Perceptual and Motor Skills, 58, 439-492.

Winston, R. B., \& Sandor, J. A. (1984). Developmental academic advising: What do students want? NACADA Journal 4(1), 5-13.

Wolfe, R. (1987). The supplemental instruction program: Developing learning and thinking skills. Journal of Reading, 31, 228-232.

Wren, C. G. (1941). Study-habit inventory (Rev. ed.). Stanford, CA: Stanford University Press.

Zimmerman, B.J. (1989). A social-cognitive view of self-regulated academic learning. Journal of Educational Psychology, 81, 329-399.

Zimmerman, B. J. (1994). Dimensions of academic self-regulation: A conceptual framework for education. In D. H. Schunk \& B.J. Zimmerman (Eds.), Self regulation of learning and performance: Issues and educational applications (pp. 3-12). Hillside, NJ: Lawrence Erlbaum Associates.

Zimmerman, B.J. (1995). Self-regulation involves more than metacognition: A social cognitive perspective. Educational Psychologist, 30, 217-221.

Zimmerman, B.J., \& Risemberg, R. (1997). Becoming a self-regulated writer: A social cognitive perspective. Contemporary Educational Psychology, 22, 73-122. 


\section{APPENDIX}

SBI Factors and Topics in the Textbook Material Used in the Experimental Treatment

\begin{tabular}{|l|l|}
\hline Textbook: Keys to Excellence- Factor 1 & \multicolumn{1}{c|}{ Textbook: Cornerstone-Factor 1 } \\
Chapter 4-Motivation and Success & $\begin{array}{l}\text { Chapter 2-Planning Your Dreams: } \\
\text { Motivation, Goal-Setting, and Self-Esteem }\end{array}$ \\
$\begin{array}{ll}\text { Introduction } \\
\text { Misconceptions about Success }\end{array}$ & $\begin{array}{l}\text { The impact of values on motivation and } \\
\text { Script for Success }\end{array}$ \\
Characteristics of Successful People & Motivation comes from within \\
& Attitude: The first step in getting what you \\
& want \\
& Overcoming doubts and fears \\
& Dealing with adversity and failure \\
& The goal-setting process \\
& Characteristics of attainable goals \\
& The impact of self-esteem on your \\
& motivation \\
& Conditions of self-esteem \\
& What makes me who I am \\
& Influences on self-esteem \\
& Behaviors associated with poor self- \\
& esteem \\
& Improving your self-esteem: Why should I \\
& do it? \\
& Ways to increase your self-esteem to \\
& accomplish goals \\
& \\
\hline
\end{tabular}


SBI Factors and Topics in the Experimental Textbook Material (continued)

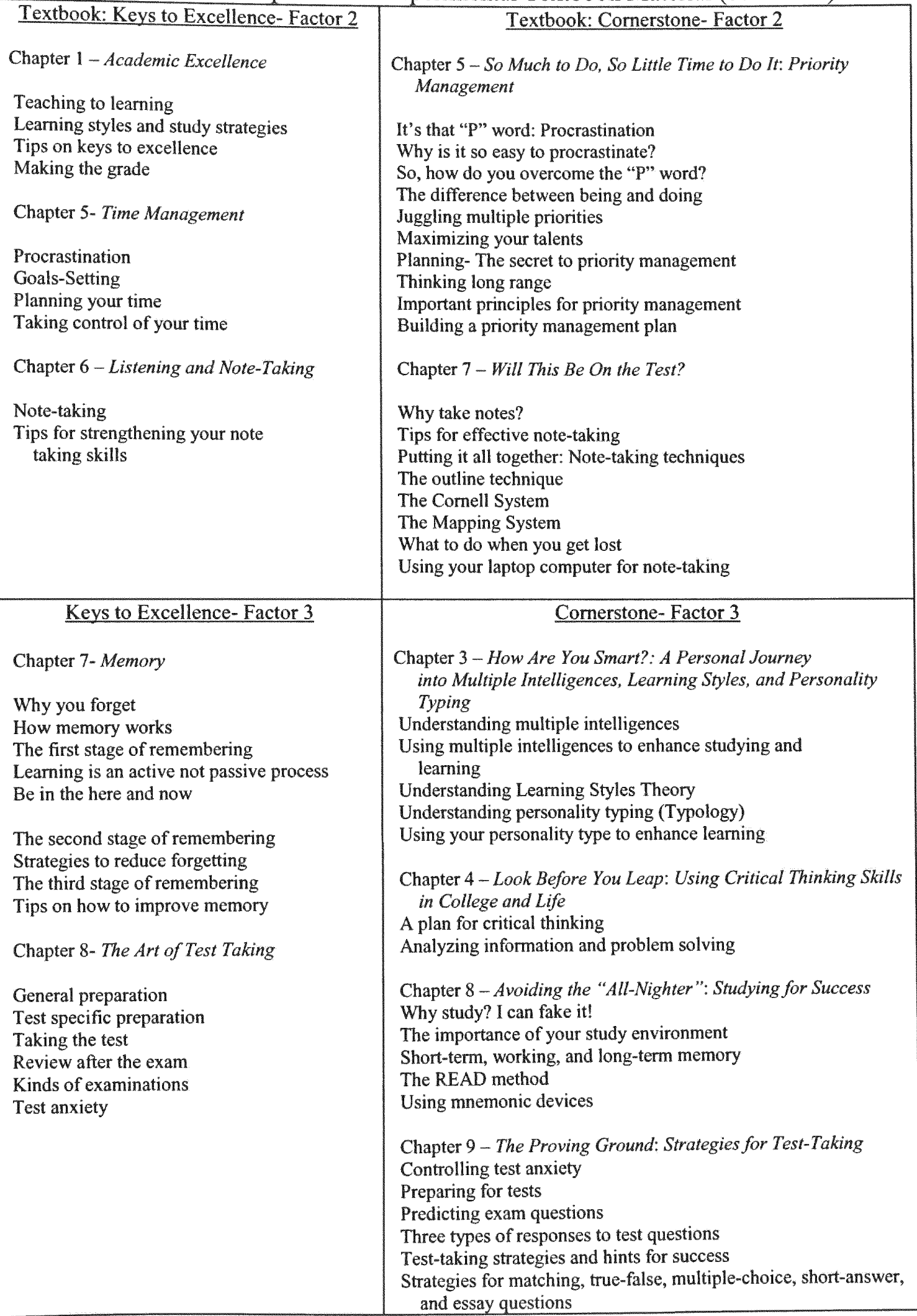




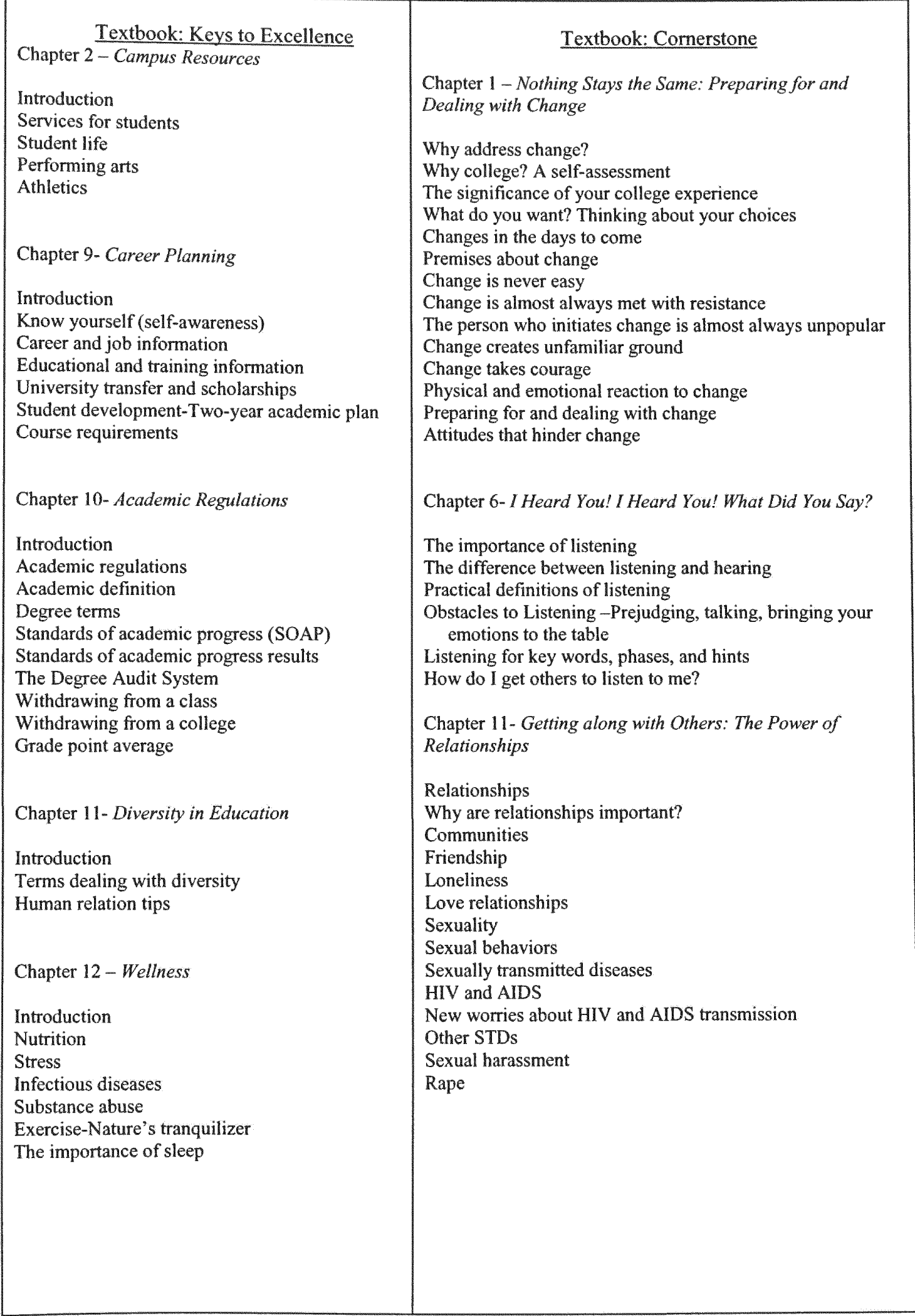


SBI Factors and Topics in the Textbook Material Used in the Control Group

Textbook: Comerstone (continued)

Chapter 12-Understanding Differences: A Celebration of Diversity

You are a culture of one

The components of culture

The power of an open mind

My culture of one

You are the center of your own universe

Changing demographics of the United States

Other components of culture

Who are you?

The golden rule for celebrating diversity

I think I would... An exercise in cultural understanding

Chapter 13- Staying Fit: A Personal Plan for Wellness

What does it mean to be healthy?

A holistic approach to wellness

Depression

Spirituality

What influences your eating habits?

Chapter 16- What Are You Doing for the Rest of Your Life?

Do you want to do something or be something?

You've got a job, Now you want a career

What do you want to be when you grow up?

Career self-study

Help me! I'm undeclared

Nine steps to career decision-making

Where to learn more about careers, majors, and work

Networking: The overlooked source for career development

World of work

Mentors-How to find a mentor? 
Born, Habana, Cuba

1987

A.A Pre-Bachelor of Arts

Miami Dade Community College

Miami, Florida

1989

B.A. Public Administration

Minor: Political Science

St. Thomas University

Miami, Florida

1993

M.A. Public Administration

Minor: International Comparative Administration

Florida International University

Miami, Florida

1991-1993

Program Coordinator, Dislocated Workers

Miami Dade College, North Campus

Miami, Florida

1994-1998

Vocational Coordinator

Business \& Technical Programs

Miami Dade College, North Campus

Miami, Florida

1998-Present

Workforce Program Coordinator

New Student Center

Miami Dade College, North Campus

Miami, Florida

2001-2002

Interim Assistant to the Academic Dean, Academic Affairs Department Miami Dade College, North Campus

Miami, Florida 